\title{
Does the Community Reinvestment Act (CRA) Cause Banks to Provide a Subsidy to Some Mortgage Borrowers?*
}

\author{
Glenn B. Canner \\ Senior Advisor \\ Board of Governors of the Federal \\ Reserve System \\ Andreas Lehnert
Board of Governors of the Federal
Reserve System
Mail Stop 93
Washington D.C. 20551
(202) 452-3325
Andreas . Lehnert @ FRB GOV
}

\author{
Elizabeth Laderman \\ Economist \\ Federal Reserve Bank of San \\ Francisco
}

\author{
Wayne Passmore \\ Assistant Director \\ Board of Governors of the Federal \\ Reserve System \\ Mail Stop 93 \\ Washington D.C. 20551 \\ (202) 452-6432 \\ Wayne.Passmore@FRB.GOV
}

This Version: April 2002

Last Revised: April 2, 2002

${ }^{*}$ The opinions, analysis and conclusions of this paper are solely ours and do not necessarily represent those of the Board of Governors of the Federal Reserve System, the Reserve Bank of San Francisco or their staffs. We thank Mary DiCarlantonio, Jamie Ingpen, Erin Klein, Judy Peng and Guillermo Pinczuk for excellent research assistance. Any remaining errors are our own. 



\title{
Does the Community Reinvestment Act (CRA) Cause Banks to Provide a Subsidy to Some Mortgage Borrowers?
}

\begin{abstract}
The Community Reinvestment Act (CRA) encourages lenders to make mortgage loans to certain classes of borrowers. However, the law does not apply to all lenders, and lenders do not necessarily receive credit for all loans made to borrowers of a particular class. Specifically, only commercial banks and savings institutions are subject to the CRA, while mortgage bankers are not. Further, CRA credit is given for loans made to higher-income borrowers who purchase homes in lower-income neighborhoods, but not to other higher-income borrowers. We use this variation to test whether or not CRA-affected lenders cut interest rates to CRA-eligible borrowers; in other words, we test for the presence of a regulationdriven subsidy. Our theory suggests that loans made by commercial banks and savings associations ("relationship lenders") and mortgage companies ("transaction lenders") will differ from one another depending on borrower risk and homeownership benefits. Empirically, we find that CRA-eligible loans at CRA-affected institutions do carry lower mortgage spreads compared with other loans at the same institution. However, once we control for risk and benefit effects suggested by our theory, these differences in mortgage spreads become economically and statistically insignificant.
\end{abstract}

Journal of Economic Literature classification numbers: G21, G28, H23, R21

Keywords: Community Reinvestment Act, mortgages, bank regulation 



\section{Introduction}

The Community Reinvestment Act (CRA) requires the federal banking agencies that supervise commercial banks and savings associations ("banks") to encourage such lenders "to help meet the credit needs of the local communities in which they are chartered, consistent with the safe and sound operation of such institutions." In practice, lenders are judged by their regulators primarily on the number and dollar amount of loans that they make to lower-income borrowers, or borrowers in lower-income neighborhoods. If lenders satisfy their auditors by attracting such borrowers with lower-than-profitable interest rates, the CRA would be a burden on the banking system. ${ }^{1}$

We test the effects of the CRA using data on home purchase mortgages made over the period 1995-2000 and variation in the institutions subject to the CRA and the types of borrowers (and neighborhoods) for whom lenders receive CRA credit. $^{2}$ These variations, however, are strongly correlated with factors influencing the nature of the mortgage contract. In our theory section, we develop a model to guide our empirical analysis. Because we embed our analysis in a general model of banking practices, our study has more general applicability. In particular, we find that, as predicted by our theory, institutions offer radically different

\footnotetext{
${ }^{1}$ For studies of the effects of the CRA on bank profitability see Canner and Passmore (1996), Avery, Bostic and Canner (2000,2002) , Board of Governors of the Federal Reserve System (1993,2000), Meeker and Myers (1996) and Malmquist, Phillips-Patrick, and Rossi (1997). For a review of the theoretical arguments surrounding CRA, see Canner and Passmore (1995b). Our paper is similar in interest to Zinman (2002), who studies the small business aspect of CRA, while we concentrate on the mortgage aspect.

${ }^{2}$ For a study of the extent of lending to lower-income borrowers by CRA-affected institutions compared to other institutions, see Canner and Passmore (1996).
} 
services; some institutions offer loans that look like classic capital-market armslength bonds, while other institutions offer loans that feature relationship-based services that, in effect, increase the borrower's credit-worthiness.

Our paper is of more general interest than as a test of the CRA; in particular, it contributes to two different bodies of literature. First, we contribute to the study of the economic effects of laws and regulations using variation in the coverage of laws. ${ }^{3}$ Our empirical work is closely guided by the theory that we develop; we show how simple atheoretical regressions would lead to incorrect conclusions. Second, we contribute to the study of the nature and role of financial institutions; in particular, how bank loans differ from bonds and other capital market instruments. ${ }^{4}$ Theoretical work in this field often presupposes that banks offer distinct services from capital markets; here we find direct evidence that this is true.

Mortgages are made by a wide variety of financial institutions to many different borrower types. The greatest distinction among lenders is between depository institutions, such as commercial banks and savings associations, on one side and mortgage companies on the other. Banks are subject to a myriad of regulations (including the CRA); at the same time, banks cultivate ongoing financial relationships with their borrowers. Mortgage companies are not subject to the same set of regulations as banks, nor do they seek a relationship with borrowers; indeed, because they so often sell their mortgages, they can be seen as a way for borrowers

\footnotetext{
${ }^{3}$ See e.g. Levitt (1997,1998) Acemoglu and Angrist (2001), Lehnert and Maki (2002), or Pence (2001) who use variations across times or space; in this paper we use variation across institutions.

${ }^{4}$ In addition to Boot and Thakor (1997,2000), see also Bolton and Freixas (2000) and Chemmanur and Fulghieri (1994).
} 
to access the capital markets. Thus, we refer to banks as relationship lenders and mortgage companies as transaction lenders.

Our theory is based on the assumption that relationship lenders have access to a credit-enhancement technology that effectively increases the borrower's repayment probability, while transaction lenders simply take the borrower's apparent credit risk as given and charge the appropriate zero-profit spread. This theory is based on the capital markets literature about firms' choice of bank or bond financing (see e.g. Boot and Thakor 2000, 1997 and the references therein). The main result of this assumption is that relationship lenders (i.e. banks) have access to a costly technology that makes borrowers better off; this is the essence of the bankborrower relationship. ${ }^{5}$ For banks to cover the cost of their credit enhancement activities they must charge higher mortgage interest rates (in turn, some borrowers will be willing to pay these rates in exchange for having their credit enhanced).

Thus, even before introducing a law like the CRA, we would observe similar borrowers being charged different mortgage rates depending on whether the borrower contracts with either a bank or a nonbank financial institution. For all but the riskiest borrowers, we show that in a competitive equilibrium, borrowers of the same apparent credit risk pay a higher mortgage rate at banks than they would at mortgage companies.

Furthermore, we show that the interest rate charged by banks (but not transac-

\footnotetext{
${ }^{5}$ Thus we study the distinction between banks and nonbank finance companies in much the same way Carey, Post and Sharpe (1998) do, although in a very different market. In addition, we concentrate on the effect of a single regulation. For more on the bank-borrower relationship, see also Sharpe (1997).
} 
tion lenders) will depend crucially on the borrower's benefit from owning a home (as opposed to renting). If we take this ownership benefit to be purely pecuniary and driven by the tax code's mortgage interest deduction, then banks would charge lower-income borrowers less than higher-income borrowers (controlling for credit quality). In effect, lower-income borrowers have a smaller surplus available to split with banks. Our theory thus suggests that banks will, in general, charge higher mortgage rates than non-banks, but that they will cut mortgage rates to their lower-income (hence lower-benefit) borrowers.

Because high-benefit (i.e. higher-income) borrowers benefit the most (controlling for credit quality) from the bank's credit-enhancement technology, our theory suggests that banks will disproportionately serve these borrowers. Lower-income borrowers (again, controlling for credit quality) will prefer to use low-cost nonbank financial institutions. The CRA, which encourages banks to serve borrowers of different incomes in proportion to their populations might, as a result, encourage banks to cross-subsidize from higher- to lower-income borrowers so that their borrower population would reflect the larger population. One might then test for such a subsidy by regressing mortgage rates against a standard set of controls and an indicator variable set to unity when a loan is both CRA-eligible and the lender is subject to the CRA. But a negative coefficient on this variable; that is, finding that CRA-affected institutions (i.e. banks) charge CRA-eligible borrowers (i.e. lower-income borrowers) less than they would have had the borrower not been CRA-eligible, or had the borrower instead gone to a transaction lender is evidence consistent with both the view that the CRA is a binding constraint on 
banks and the view that banks provide costly credit-enhancement services.

Thus, our theory forces us to confront a serious identification issue as we try to discriminate between these two hypotheses. Specifically, it is precisely those institutions with access to the credit enhancement technology (i.e. banks) that are subject to the CRA and it is mostly those borrowers with a relatively low benefit (i.e. lower-income borrowers) to homeownership that are eligible for CRA credit. If we could observe the benefit to homeownership, and if this benefit did not vary precisely with CRA eligibility, then we could confidently test the hypothesis that the CRA causes banks to subsidize loans to certain borrowers. In such a happy circumstance, we would regress mortgage rates on the standard set of controls and, as additional regressors, borrower credit risk and benefit to homeownership interacted with an indicator variable for relationship lenders. In such a specification, if the coefficient on a variable interacting CRA eligibility with lender type still showed banks cutting rates to CRA-eligible borrowers, we would take this as evidence of a subsidy.

We take two approaches. First, we make no attempt to control for the borrower's benefit to homeownership. This provides us with an upper bound on the potential subsidy extended by banks. Second, we make the identifying assumption that the benefit to homeownership is purely pecuniary and driven only by the mortgage interest deduction in the tax code. Under this assumption, higherincome borrowers will benefit the most from homeownership, and this benefit will not be affected by the location of the home. Effectively, banks receive CRA credit for higher-income borrowers only if the borrower purchases a home in a 
lower-income neighborhood. By restricting our dataset to solely higher-income borrowers, we approach our ideal dataset, because, under our identifying assumption, CRA eligibility (i.e. buying a house in a lower-income neighborhood) does not affect the benefit of homeownership. We then test whether higher-income borrowers receive lower interest rates at banks, but not transaction lenders, if they buy a house in a lower-income neighborhood. Under our identifying assumption, the existence of lower rates would be evidence of a subsidy.

Under our first approach, we find that the upper bound on the potential subsidy is tiny: at the very most, it amounts to less than six basis points. Under our second approach, we can in general go further and reject the hypothesis of a subsidy (although under certain definitions of higher-income, our results indicate the presence of a small subsidy). Thus, we conclude that the CRA does not cause banks to extend mortgage loans with substantially lower mortgage rates to attract CRA eligible borrowers.

The plan of this paper is as follows: section 2 reviews the salient features of the CRA, section 3 lays out our model and associated analysis, section 4 describes in some detail the construction and nature of our data, section 5 presents our results and section 6 briefly concludes. We include further information on the construction of our final dataset and an analysis of households' propensity to itemize their deductions in an appendix. All tables are at the end of the paper. 


\section{The Community Reinvestment Act}

The CRA was enacted in 1977 and is intended to encourage commercial banks and savings associations to help meet the credit needs of the local communities in which they are chartered. In adopting the CRA, the Congress reaffirmed the principle that depository institutions have an obligation under their charters to serve "the convenience and needs" of their communities by extending credit to all parts of those communities. ${ }^{6}$

The CRA is directed primarily at four federal supervisory agencies-the Board of Governors of the Federal Reserve System, the Comptroller of the Currency, the Federal Deposit Insurance Corporation, and the Office of Thrift Supervision. The Act calls upon these agencies to (1) use their supervisory authority to encourage each financial institution to help meet local credit needs in a manner consistent with safe and sound operation, (2) assess an institution's record of meeting the credit needs of its entire community, including lower-income neighborhoods, and (3) consider the institution's CRA performance when assessing an application for a charter, deposit insurance, branch or other deposit facility, office relocation, merger, or acquisition.

To enforce the CRA, the regulatory agencies conduct periodic CRA examinations of commercial banks and savings associations and, as required by the statute, evaluate CRA performance during the application process for bank acquisitions, mergers and other actions. The vagueness of the affirmative responsibility placed

\footnotetext{
${ }^{6}$ For an overview of the history of the CRA, see Garwood and Smith (1993).
} 
on lenders by the Congress has made it difficult for the regulatory agencies to determine compliance with the CRA. Most institutions receive a rating of satisfactory or better on their CRA performance, and few institutions have had their applications for mergers or acquisitions denied. The CRA has, however, prompted institutions to undertake specific actions to enhance their CRA performance before and during the application process; for an overview of these programs and their profitability, see Avery, Bostic, and Canner (2000).

In 1995, the agencies began implementing a revised CRA regulation that uses three distinct performance-based measures: a lending test, an investment test and a service test. ${ }^{7}$ These tests combine the judgment of CRA examiners with quantitative measures of performance, such as the ratio of mortgages extended to lower-income borrowers to all mortgages and the ratio of mortgages extended in lower-income neighborhoods to all mortgages. When adopting the new regulation, the agencies noted that the examination process is inherently subjective and requires that performance be measured within the context of (1) a community's credit needs and (2) the capability of the lender. These two standards are referred to as the "performance context".

The CRA legislation places a heavy emphasis on the analysis of the geographic distribution of an institution's lending across its entire community. The current CRA regulation implements this legislative intent by classifying neighborhoods in a lender's CRA assessment area as low-, moderate-, middle-, or higher-income. A

\footnotetext{
${ }^{7}$ In this paper, we focus exclusively on the lending test portion of CRA regulation (see 12 CFR 228, regulation BB "Community Reinvestment"; section 28 contains the lending test).
} 
low-income area is defined as an area where the median family income is less than 50 percent of the median family income for the broader area (such as a metropolitan statistical area or MSA). In a moderate income area, the median family income is at least 50 percent and less than 80 percent of that for the broader area. In a middle-income area, the percentages range from at least 80 percent up to 120 percent. And in a higher-income area, the percentage is at least 120 percent. These income definitions divide the population and the number of census tracts into groups of unequal size, with far fewer people, owner-occupied homes, and census tracts in the lower-income groups. ${ }^{8}$ We will refer to neighborhoods (or borrowers) with less than 80 percent of the MSA median family income as lower-income neighborhoods (or borrowers).

The current CRA regulation also extends the evaluation of a bank's lending to encompass the distribution of loans across low-, moderate-, middle-, and higherincome borrowers, where the income categories follow the same groupings as neighborhoods but rely on the individual's income relative to that of the borrower's MSA or broader non-metropolitan area median family income for individuals residing outside an MSA. Thus, while continuing to place a heavy emphasis on the geographic distribution of an institution's lending, the agencies also favorably consider loans made to lower-income individuals.

One result of this dual approach (considering both the borrower's own income as well as the income of the neighborhood in which the borrower seeks to purchase a home) is that loans to higher-income borrowers are favorably considered

\footnotetext{
${ }^{8}$ See Canner and Passmore (1995b).
} 
by regulators for CRA purposes only if the borrower is purchasing a home in a lower-income neighborhood. Indeed, loans to higher-income borrowers not purchasing homes in lower-income neighborhoods might be seen as counting against the lender for CRA purposes, because regulators use the ratios of loans to higherand lower-income borrowers relative to the total as two yardsticks to gauge a lender's CRA performance. We exploit this fact in our empirical work below.

CRA examinations consider a broad range of loan products, including all types of residential, consumer, and business loans. Our paper is focused only on home purchase lending, an important component of the lending test, because the data available pursuant to the Home Mortgage Disclosure Act (HMDA) allow the empirical investigation of the nature and extent of this type of lending by the mortgage industry to different neighborhoods and different borrowers in all MSAs. ${ }^{9}$

\section{A Model of Competitive Banking and Provision of}

\section{Mortgage Loans}

The mortgage market is characterized by a variety of institutions that serve different types of borrowers. In our model, we assume that financial institutions have full information about all borrowers, but provide different levels of service (or "relationships") to borrowers. This view could be easily modified to incorporate the

\footnotetext{
${ }^{9}$ The HMDA requires financial institutions with offices in metropolitan areas to provide information on the geographic location of the properties related to the home loans they originate or buy. HMDA also requires lenders to disclose information on the disposition of home loan applications, the date of the loan, and on the race or national origin, gender, and annual income of loan applications or borrowers.
} 
assumption that financial institutions have only partial information about borrowers (thus adding the possibility of adverse selection) and must undertake costly background checks to verify a borrower's true credit risk. The main conclusions from the model would be unchanged.

Bankers often distinguish themselves from other sorts of lenders by saying they develop a relationship with their borrowers. In the mortgage markets, one might pose a stylized contrast between mortgage companies, who focus exclusively on mortgage transactions and with whom the borrower is unlikely to have repeat transaction in the near future, and banks, who develop a long-standing relationship with the borrower and provide other financial services to that borrower over time. Another element of this stylized contrast is that mortgage companies are usually funded by the capital markets and generally sell their mortgages in secondary mortgage markets, whereas banks are funded by both the capital markets and retail deposits, and sometimes hold their mortgages in their portfolios. In addition, banks are subject to extensive regulation and supervision both for safety and soundness and for community reinvestment, whereas independent mortgage companies are, for the most part, free of such regulation, particularly as regards community reinvestment.

\subsection{Borrower and Lender Types}

In our model, the mortgage applicant has the choice of borrowing from relatively high-cost relationship lenders (which we identify as banks) or from low-cost transaction lenders (which we identify as independent mortgage companies). However, 
before determining what type of institution from which to obtain a mortgage, applicants first need to decide whether they wish to purchase or rent housing. Over all but the shortest horizons, and for all but the lowest-income households, purchasing offers a clear advantage over renting (see Henderson and Ioannides (1983) and the large literature that followed it). The one exception to this rule is if the homeowner defaults and suffers foreclosure. Although the specific details of foreclosure law vary among states (Pence, 2001), there is little question that renting beats being evicted.

To begin, we assume that all financial intermediaries can observe a borrower's probability of repayment $(\theta=[0,1])$ without incurring any costs. The borrower's utility is:

$$
U_{B U Y}=\left\{\begin{aligned}
B-R & \text { with probability } \theta \\
-\delta & \text { with probability } 1-\theta
\end{aligned}\right.
$$

Here $B$ is the net benefit to the borrower of owning a house (relative to renting), and $R$ is the interest payment on the mortgage. We normalize the utility of renting so that:

$$
U_{\text {RENT }}=0
$$

The expected utility a borrower of type $\theta$ is:

$$
E\left\{U_{B U Y} \mid \theta, R\right\}=\theta(B+\delta-R)-\delta
$$


For the expected utility of buying to exceed the utility of renting, interest payments cannot be too high; we can thus derive a schedule of maximum interest rates that borrowers would be willing to pay before renting:

$$
R_{\max }(\theta)=B+\delta-(\delta / \theta)
$$

Mortgage companies, in contrast to banks, are assumed to make only transaction or commodity loans; that is, loans that require little contact between the borrower and lender. Using a competitive capital market for the initial funding of a loan and then selling the loan into the capital markets, we model mortgage companies as a competitive industry with zero economic profits. Thus, the transaction loan rate, $R_{T}$, will satisfy:

$$
\theta R_{T}=\rho+c_{T}
$$

where $\rho$ is the capital market funding cost for the loan and $c_{T}$ is the per-mortgage origination cost for transaction lenders. ${ }^{10}$

Borrowers can also turn to the banking industry for a mortgage loan. The banking industry can duplicate the behavior of mortgage companies or it can provide relationship loans; that is, loans where the lender undertakes some costly actions that decrease the probability that the borrower defaults. For example, bankers might encourage and offer financial or homebuyer education to some bor-

\footnotetext{
${ }^{10}$ The purchaser of the mortgage from the mortgage banker discounts the mortgage rate by the expected default loss and, for ease of presentation, we assume that a defaulted mortgage has no value. In other words, the expected return on the mortgage is $\theta R+(1-\theta) 0$.
} 
rowers or might provide neighborhood-based loan officers that spend some time becoming familiar with the people and characteristics of a particular area. In addition, banks might be able to use information gleaned from their depository role to provide valuable services to their borrowers. Each relationship loan will have an origination cost $c_{R}>c_{T}$ and an additional adjustment cost related to the amount of credit enhancement undertaken by the lender, $\gamma$.

The bank's expected profits per dollar of mortgage loan are:

$$
\pi\left(\gamma, R_{R}\right)=\bar{\theta}(\gamma) R_{R}-\frac{\gamma^{2}}{2 a}-\left(\rho+c_{R}\right), \text { where } \gamma \in[0,1], a>0
$$

Here, $\bar{\theta}$ is the credit-enhanced probability of repayment, defined as:

$$
\bar{\theta}=\theta+(1-\theta) \gamma, \text { where } \bar{\theta} \in[\theta, 1]
$$

\subsection{Competitive Equilibrium}

Assuming a competitive relationship lending (i.e. banking) industry, bankers will compete to offer the best feasible contract to each borrower of type $\theta$. Banks choose the mortgage rate, $R_{R}$, and the degree of credit enhancement, $\gamma$, to maximize the borrower's expected utility, $V(\theta)$. That is, banks must solve the problem:

$$
V_{R}^{\star}(\theta)=\max _{R_{R}, \gamma} E\left\{U_{B U Y} \mid \bar{\theta}(\gamma), R_{R}\right\}, \text { subject to: } \pi\left(\gamma, R_{R}\right) \geq 0
$$


Here $V_{R}^{\star}(\theta)$ is the borrower's expected utility from taking an optimal relationship loan. If competition forces the profit per loan to zero, then (from equation 6), we can derive a relationship between the mortgage interest rate at relationship lenders, $R_{R}$, and the quantity of credit enhancement undertaken by the lender, $\gamma$ :

$$
R_{R}(\gamma)=\frac{1}{\bar{\theta}}\left(\frac{\gamma^{2}}{2 a}+\rho+c_{R}\right)
$$

By substituting this condition into the bank's problem, equation (8), we can derive the utility-maximizing level of credit enhancement:

$$
\begin{aligned}
& \gamma^{\star}=a(1-\theta)(B+\delta), \text { so: } \\
& \bar{\theta}^{\star}=\theta+a(1-\theta)^{2}(B+\delta) .
\end{aligned}
$$

Substituting this result into the borrower's valuation of the mortgage, we can derive a closed-form solution for $V_{R}^{\star}(\theta)$ :

$$
V_{R}^{\star}(\theta)=(B+\delta) \theta+\frac{a}{2}(B+\delta)^{2}(1-\theta)^{2}-\left(\delta+\rho+c_{R}\right) .
$$

The value to the borrower of choosing a relationship loan in a competitive banking environment, $V_{R}^{\star}(\theta)$, is quadratic in the borrower's initial repayment probability. Further, although the quantity of credit enhancement undertaken by the relationship lender is decreasing in $\theta$, the effective repayment probability, $\bar{\theta}$, is non-monotone in $\theta$.

Examples of these policies are shown in figure 1. The top panel of the fig- 
ure shows how the post-enhancement probability of repayment, $\bar{\theta}$, relates to the pre-enhancement probability, $\theta$. The non-monotone relationship is driven by the amount of relationship investment, $\gamma$, shown in the middle panel. As the borrower's own credit quality increases, the relationship lender performs less credit enhancement (that is, invests less in the relationship with the borrower), thus augmenting the borrower's credit quality less. These top two panels display graphically the relationships derived in equation (10). The bottom panel shows how the mortgage interest rate charged by the relationship lender, $R_{R}$, varies with $\theta$. Notice that $R_{R}(\theta)$ is decreasing in $\theta$, but that it is relatively flat for low credit-quality borrowers (near $\theta=0$ ).

Next, we compute the value to the borrower of choosing a transaction loan, $V_{T}^{\star}(\theta)$. By substituting $R_{T}$ (from equation 5), into the borrower's expected utility from purchasing a house (from equation 3), we get:

$$
V_{T}^{\star}(\theta)=(B+\delta) \theta-\left(\delta+\rho+c_{T}\right)
$$

Notice that $V_{T}^{\star}$ is linear in $\theta$, with a lower intercept and larger slope than $V_{R}^{\star}$.

Borrowers with substantial credit risk will prefer to rent rather own a home. We can define a critical level of credit risk, $\theta_{L}$, where all borrowers with $\theta<\theta_{L}$ will choose to rent.

At the other extreme, some borrowers are almost certain to repay their mortgages even without any credit enhancement, and gain little from credit enhancement. These borrowers will always seek a transaction loan, and we can define 
Figure 1: Optimal policies of relationship lenders
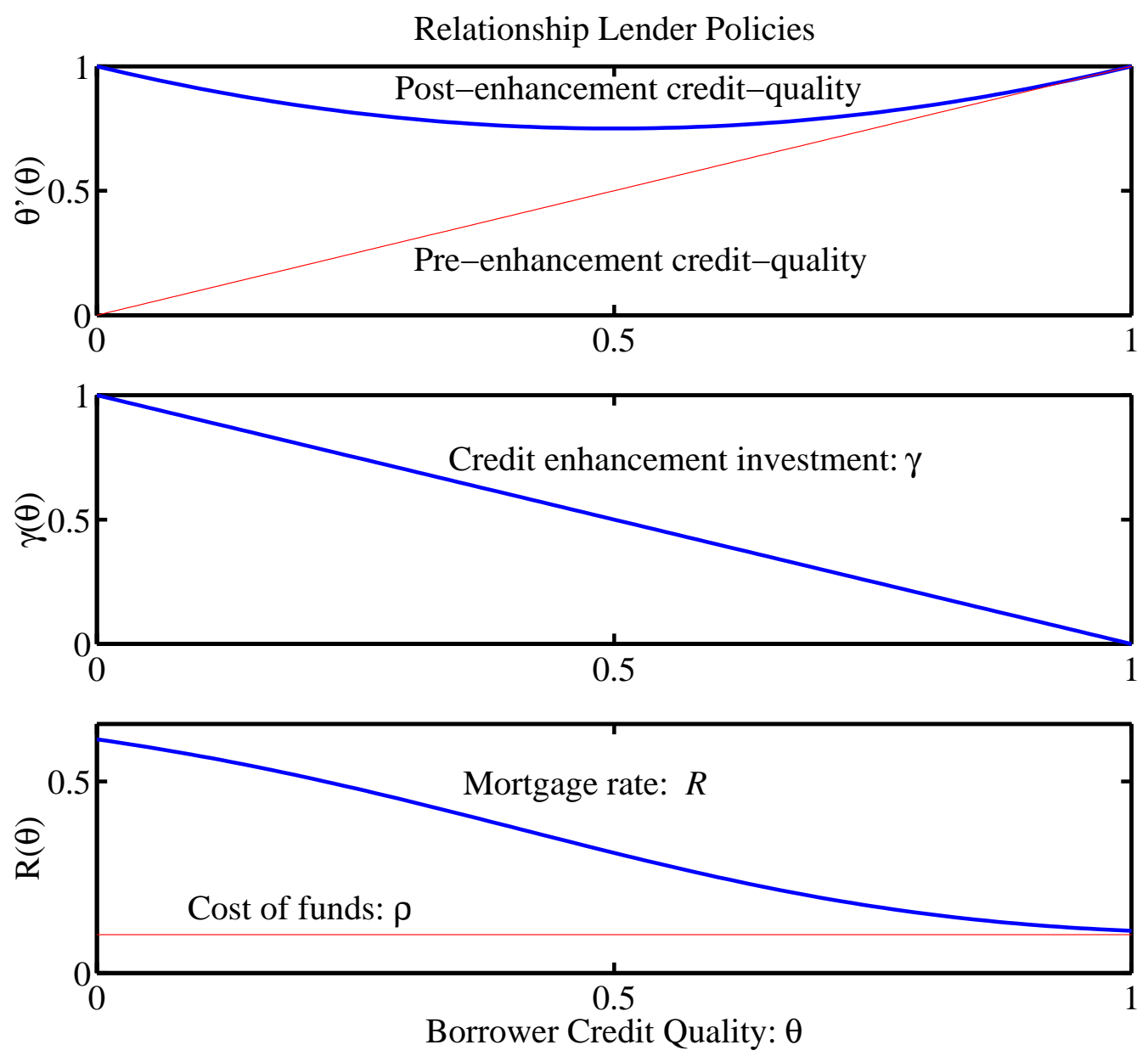

NOTE. Figure shows optimal policies of relationship lenders (banks) as functions of borrower credit quality (the repayment probability $\theta$ ). In this example, the benefit to homeownership is $B=0.95$, the cost of default is $\delta=0.05$, the origination cost is $c_{R}=0.01$ and the net cost of funds is $\rho=0.10$. 
another critical value, $\theta_{T}$, where borrowers with $\theta>\theta_{T}$ will not use a bank. By setting $V_{R}^{\star}\left(\theta_{T}\right)=V_{T}^{\star}\left(\theta_{T}\right)$, we can solve for this level of credit risk:

$$
\theta_{T}=1-\frac{\sqrt{(2 / a)\left(c_{R}-c_{T}\right)}}{B+\delta}
$$

If the fixed loan origination costs for the bank and mortgage company are equal $\left(c_{R}=c_{T}\right)$, the critical level of $\theta_{T}$ is unity; everyone takes out a relationship loan because the relationship lender can perfectly replicate the transaction lender. Because we view relationship loans as usually more expensive than transaction loans (that is, we take $c_{R}>c_{T}$ ) this critical level will be below unity and some high-quality borrowers will go to the mortgage companies.

In figures 2 and 3, we graph the expected utility of agents and the mortgage interest rate respectively as a function of $\theta$. The critical points $\theta_{L}$ and $\theta_{T}$ are marked on the graphs. Note that even though a transaction lender may be willing to make a loan at a significantly lower interest rate than that charged by the relationship lender, some borrowers find it better to use the credit enhancement technology of the relationship lender.

\subsection{Varying Homeownership Benefits}

So far we have not addressed the benefit to homeownership, $B$. Now assume that there are two borrower populations: A lower-benefit population (with low values of $B$ ) who make up a proportion $\alpha$ of the total and a higher-benefit population (with higher values of $B$ ) who make up the remaining $1-\alpha$. The two populations 


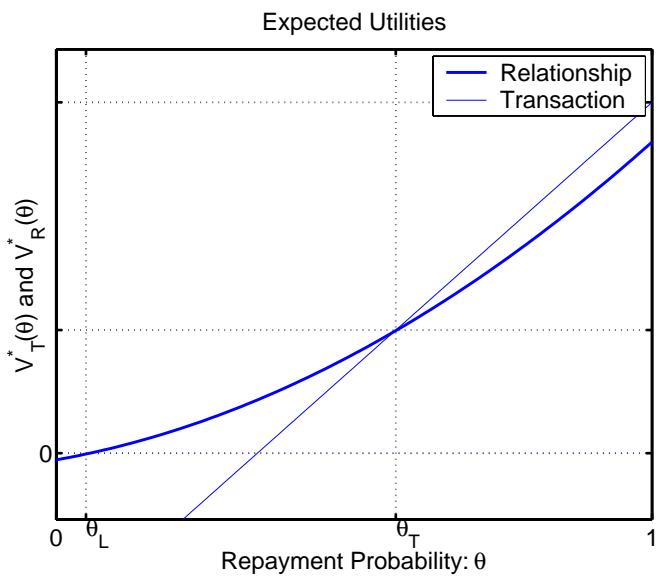

Figure 2: Expected Utility

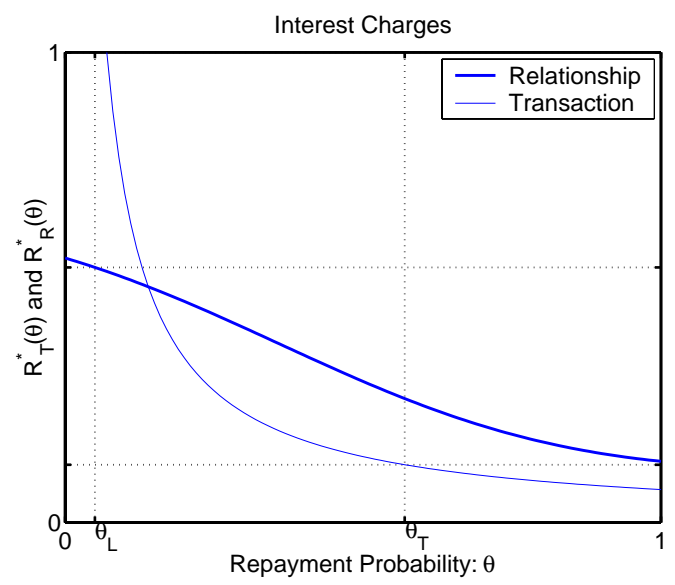

Figure 3: Interest Rates

will be otherwise identical. The key difference between them will be that the benefit to homeownership net of the benefit to renting will be lower for the lowerbenefit group.

We cannot observe the private benefit to homeownership (as opposed to renting) directly. However, we can assume that this benefit is at least correlated with the borrower's income, so that high-income agents are more likely to be highbenefit. This is a sensible assumption because at least part of the benefit of homeownership is driven by a government policy that encourages homeownership. The U.S. income tax code is also progressive, so that the homeownership subsidy is lower for lower income groups. Brady, Cronin, and Houser (2001) quantify this starkly, showing that the effective mortgage interest deduction subsidy rate is more than twice as large for households jointly earning between $\$ 75,000$ and $\$ 100,000$ as it is for households jointly earning less than $\$ 50,000$ per year.

We model the different benefits to ownership associated with each benefit 
group as different levels of the net benefit $B$ of homeownership over renting. Associated with each level of $B$ will be different values of the critical points $\theta_{L}$ and $\theta_{T}$. Lower-income households, by virtue of their lower benefit $B$, will be more likely to rent, all else equal. Thus $\theta_{L}$ will be higher for the lower income group. By the same token, they will have less surplus to split with the relationship lender (the gains from credit enhancement will be lower) and $\theta_{T}$ will shift to the left. ${ }^{11}$

The expected utilities of both types of borrower (high and low benefit) under each type of loan are displayed in figure 4 . The associated interest rates are displayed in figure 5. As expected, the transaction lenders do not alter their interest rates by type of borrower. Relationship lenders, however, lower their interest rates when dealing with lower-income borrowers. They are also undertaking less credit enhancement.

Even without CRA resulting in a subsidy, if the world were like our model, we would observe similar borrowers being charged different interest rates depending on what type of institution the borrower contracts with. Borrowers at banks would be charged a higher interest rate, controlling for observable credit quality measures, but would benefit from the banks' credit-enhancement technology. According to our theory, lower-income borrowers at banks would be charged less than

\footnotetext{
${ }^{11}$ If we assume that higher- and lower-income borrowers have the same distribution of credit quality $\theta$, one immediate result of our analysis is that of all the borrowers serviced by relationship lenders, a proportion less than $\alpha$ will be low-benefit; and of all the borrowers serviced by transaction lenders, a proportion above $\alpha$ will be low-benefit. Thus banks will have fewer lowerincome (or, more generally, lower-benefit) borrowers than mortgage companies, despite the fact that banks perform a valuable credit-enhancement service. Further, banks will have fewer lowerincome borrowers than the overall borrower population. This result, which may seem at odds with the conventional wisdom, can be overcome if we assume that lower-income borrowers are more likely to have default probabilities $\theta$ within the range serviced by banks, $\left[\theta_{L}, \theta_{T}\right]$.
} 


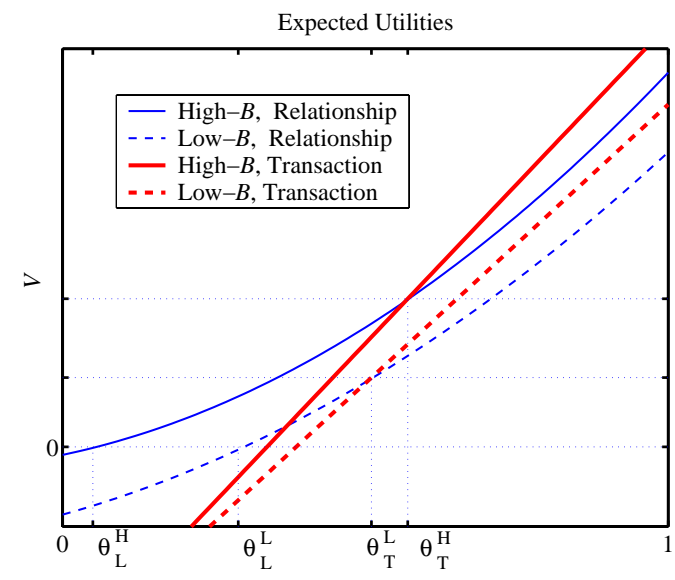

Figure 4: Expected Utility

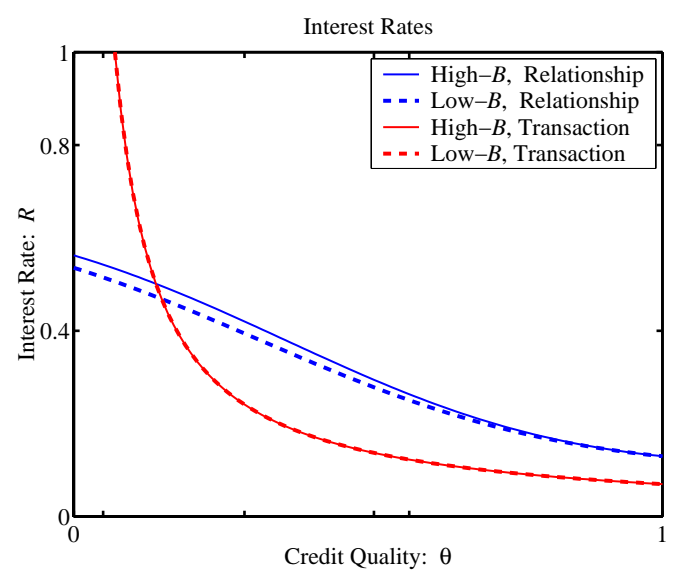

Figure 5: Interest Rates

higher-income borrowers at banks, holding credit risk constant, because lowerincome borrowers receive fewer benefits from homeownership. Lower-income borrowers at banks may or may not pay higher rates than such borrowers at transaction lenders, depending on their level of credit risk. Thus, a researcher who compares the mortgage rates of lower-income borrowers to higher-income borrowers at banks, or the mortgage rates of lower-income borrowers at relationship lenders to those at transaction lenders, has performed the incorrect "natural experiment" to test for a CRA-driven subsidy because he did not correct for (1) the benefit to homeownership and (2) the differing products offered by relationship and transaction lenders.

However, our theory does suggest at least one natural experiment if we believe that the benefits of homeownership are highly correlated with income. This is a natural assumption because the primary pecuniary benefit to homeownership in the United States is probably the mortgage interest deduction; but only relatively 
higher-income borrowers itemize their deductions and hence benefit from this tax break. But mortgages to higher-income borrowers receive CRA credit only if the loan is for the purchase of a home in a lower-income neighborhood. Thus, we can focus on higher-income borrowers locating in lower-income neighborhoods as a way to identify the effects of CRA. As a first experiment, if these borrowers (holding credit risk constant) pay lower mortgage rates at banks relative to other higher-income borrowers at banks, then there is evidence of a CRA subsidy. As a second experiment, if these borrowers (holding credit risk constant) pay lower mortgage rates when the mortgage is offered by a relationship lender rather than a transaction lender, then there is also evidence of a CRA subsidy.

\section{Data}

It is difficult to come by data to empirically test the effects of CRA. ${ }^{12}$ The HMDA data is the main public source of mortgage borrower information, but lacks information on pricing (including whether or not the borrower is paying for private mortgage insurance) and the value of the property securing the mortgage. Here, we merge the HMDA data with two other datasets: first, the Mortgage Interest Rate Survey (MIRS) collected by the Federal Housing Finance Board and, second, data on mortgages with private mortgage insurance collected by the Federal

\footnotetext{
${ }^{12}$ However, there are a few studies: Avery, Bostic and Canner $(2000,2002)$, Board of Governors of the Federal Reserve System (1993,2000), Canner and Passmore (1996), Canner, Passmore, and Surette (1996), Evanoff and Segal (1996, 1997) and Harvey, Collins, Nigro, and Robinson (2001).
} 
Financial Institutions Examination Council (FFIEC). ${ }^{13}$

HMDA provides information on residential mortgages (including their type: conventional or government-backed), purpose of the loan (home purchase, home improvement, or refinancing), and the amount of the loan. In addition, HMDA includes some information about borrowers (including income, race, ethnicity, and gender), as well as the lender type (commercial bank, savings association or mortgage bank), and location of the property securing the loan (state, MSA, county and census tract). With the property location, the characteristics of the neighborhood the property is located in can be determined from the 1990 Census of Population and Housing. The MIRS collects pricing information on mortgages, including the contract interest rate, points, the effective interest rate and term to maturity, but only covers conventional home purchase loans. ${ }^{14}$ It also includes the loan amount, property value and loan-to-value ratio for the mortgage and the location of the property by zip code. Finally, the FFIEC data on private mortgage insurance (PMI) identifies the lender, location of the property by census tract, loan amount and characteristics of the borrower (e.g. race, ethnicity, gender and income) for each conventional mortgage backed by PMI.

We briefly describe in this section the procedure used to match records from these three separate datasets. A more complete description of the procedure can be found in the appendix. We also present some statistics that allow an evaluation

\footnotetext{
${ }^{13}$ For an evaluation of an earlier two-way match between HMDA and MIRS data, see Canner and Passmore (1995a).

${ }^{14}$ The effective interest rate accounts for both the contract interest rate, and points and fees paid by the borrower. As such the effective rate is a more accurate representation of the mortgage rate than the contract rate.
} 
of the quality of the match.

There is no unique borrower identifier (such as borrower name, social security number or street address) in any of these databases nor is there a unique lender identifier across all three databases, so we "statistically" matched the loan records on conventional home purchase mortgages across the three databases using the following procedure. Broadly speaking, first, we use the date the mortgage was closed from each database to determine the month of mortgage origination. Second, we converted property identifiers in HMDA into zip codes and grouped the HMDA and FFIEC PMI data records by zip codes. Only loans located in MSAs were considered in our analysis.

At this point, we had a set of mortgage loans from each database for each month of the years 1995 to 2000 grouped by zip code. For each of these monthlocation groups, we matched records in HMDA and MIRS using the loan amount. Records with the least difference in loan amount were matched and kept unless the absolute difference was greater than $\$ 2,000$; in this case, no match was made. The result was a set of statistically matched borrower/loan records that contained both the HMDA and MIRS information.

The PMI information was added to these HMDA/MIRS matched records using another statistical match. For the records in a particular month-location group, we matched the PMI to the HMDA/MIRS record based on loan amount (using the $\$ 2,000$ absolute difference again), and borrower race and ethnicity (which had to be exact matches). ${ }^{15}$

\footnotetext{
${ }^{15}$ For a complete description of the statistical matching procedure see appendix A.1; for diag-
} 
Although the resulting data contains information on adjustable-rate mortgages, 15-year fixed-rate mortgages and 30-year fixed-rate mortgages, we eliminated all observations that did not relate to a 30 -year fixed-rate mortgage. Such mortgages made up about $90 \%$ of our data, and by concentrating solely on a single financial product, we could compare interest rate spreads directly, without having to control for amortization length or the fixed/floating spread. See appendix A.3 for evidence that mortgage type and CRA eligibility are not related.

Our empirical analysis will feature a full set of lender and MSA fixed effects; if a particular lender or MSA appears only seldom in our sample, the fixed effect may completely absorb any identification provided by those observations. Further, we want to concentrate on active lenders, as opposed to lenders who make few loans (of the type we study) per year. Thus we impose two conditions on each observation for it to be included in our final dataset. First, we require that each observation come from an institution that comprises at least 0.1 percent of our original database. Second, we require that each observation come from an MSA that also comprises at least 0.1 percent of our original database. ${ }^{16}$

The original dataset contained information on 314,009 conventional home purchase mortgages made by 2,685 different lenders in 304 different MSAs; about 76 percent of the mortgages in the original dataset were made by relationship lenders (commercial banks, saving associations and their mortgage affiliates). After apnostics of the match quality, see appendix A.2.

${ }^{16}$ Further, the survey conducted by the FHLB to construct the MIRS excludes very small lenders; for this reason, excluding less-active lenders from our dataset probably purges some spurious matches. 
plying our two conditions, we are left with a final dataset containing 250,593 mortgages made by 84 different lenders in 144 different MSAs; about 77 percent of the mortgages in this final dataset were made by relationship lenders. ${ }^{17}$

The resulting dataset appears to closely mirror characteristics of the wider mortgage market. Figure 6 compares the time series of the spread in our data to the Freddie Mac conforming mortgage index; also, the figure compares the number of observations in our data (per month) to the Mortgage Banker's Association purchase index. The mean spread in our data tracks the spread from Freddie Mac's primary mortgage market survey (PMMS) quite well, with a correlation of about 90 percent. The mean spread in our data, however, consistently exceeds Freddie Mac's published average, probably because our data include non-conforming and high LTV mortgages; further, we use the effective rate on the mortgage while the index tracks the contract rate and points separately. Meanwhile, the monthly pattern of observations in our data closely mirrors the pattern in the Mortgage Banker's Association (MBA) purchase index, with a correlation of about 90 percent between the two series. Also, notice that our data also mirror the clear trend in the MBA index across years, not just the intra-year seasonal pattern.

\footnotetext{
${ }^{17}$ For the purposes of CRA examination, banking institutions can choose to include the mortgage lending of their mortgage affiliates.
} 
Figure 6: Comparisons between our dataset and wider mortgage market indicators

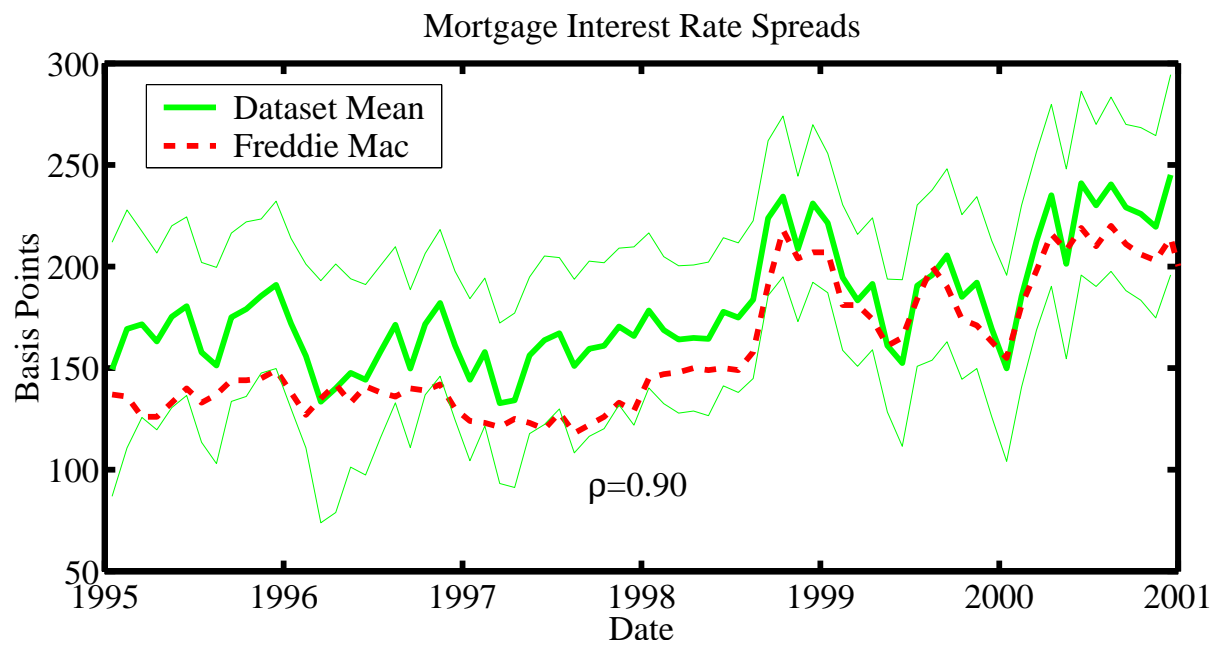

(a) Spreads

Mortgage Activity

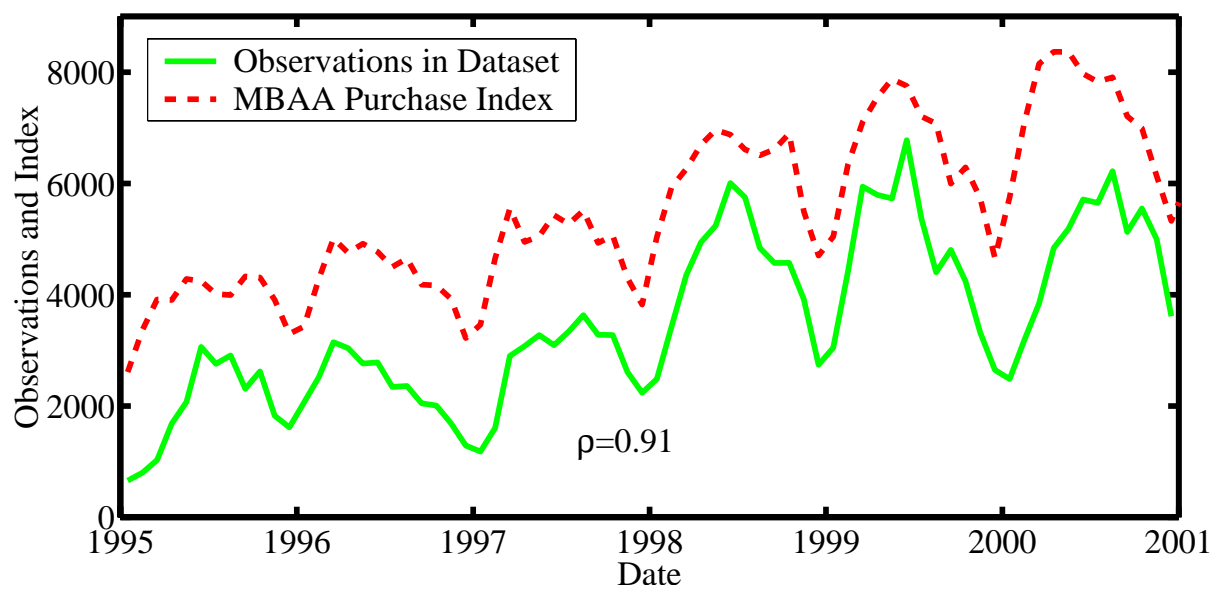

(b) Observations

NoTE. The top panel of the figure compares the mean monthly mortgage interest rate spread in our data to the Freddie Mac mortgage rate index. The bottom panel of the figure compares the monthly number of observations in our dataset to the Mortgage Banker's Association of America (MBAA) purchase index. 


\section{Empirical Specification and Results}

\subsection{Identification of a Subsidy}

\section{Identifying Assumptions}

We believe, a priori, that independent mortgage companies are most like the transaction lenders in our model and that all other lenders (commercial banks and savings associations) are most like the relationship lenders in our theory.

Under our theory, a subsidy would result in CRA-eligible borrowers getting lower mortgage spreads at relationship lenders relative to other borrowers at relationship lenders, holding constant the borrower's credit risk and the borrower's benefit to homeownership. Further, our theory predicts that the difference in interest rates charged the same borrower at a transaction lender and at a relationship lender will depend only on the borrower's risk characteristics and homeownership benefit. In an ideal world, in which borrowers are distributed randomly among lenders and the lenders were randomly subject to the CRA, we could identify a subsidy by regressing mortgage spreads on variables related to the borrower's riskiness, the prevailing cost of funds, MSA and institutional dummies and other variables related to the local competitive environment and then interacting lender type only with those variables related to the borrower's riskiness, benefit to homeownership and CRA eligibility. If the estimated effect of CRA eligibility at CRAaffected institutions were negative in this regression, we would conclude that the CRA was causing affected lenders to attract CRA eligible borrowers with lower 
mortgage rates than the lenders would normally charge such borrowers, i.e. that the CRA caused banks to subsidize mortgages to eligible borrowers. In the data, though, only relationship lenders are subject to the CRA; and, further, the benefit to homeownership is probably correlated to a borrower's CRA-eligibility.

We pursue two strategies to identify the effect of CRA. First, we ignore completely the borrower's benefit to homeownership and instead identify the CRA interaction term as an upper bound on any subsidy. Second, we assume that the benefit to homeownership is largely tax driven. ${ }^{18}$ Under this assumption, only higher-income borrowers are high-benefit and locating in a lower-income neighborhood does not lower that benefit. We then restrict our sample to higher-income borrowers only and identify the effect of CRA as the effect of making a loan to a higher-income borrower in a lower-income neighborhood. As a robustness check, we use several different criteria to identify households as higher-income (and hence high benefit).

Our theory tells us that under the null hypothesis of no subsidy, the spread on mortgage $j, S_{j}$, should be given by:

$$
\left(H_{0}\right) \quad S_{j}=f\left(\theta_{j}\right)+R_{j} f_{\lambda}\left(\theta_{j}\right)+\gamma_{\lambda} R_{j} g_{j}+\alpha C_{j}+\mathbf{X}_{j} \mathbf{B}+u_{j}
$$

Here $\theta_{j}$ is the credit-worthiness and $g_{j}$ the homeownership benefit of borrower $j ; R_{j}=\{0,1\}$ indicates whether the loan was made by a relationship lender and

\footnotetext{
${ }^{18}$ See Brady, Cronin, and Houser (2001) for evidence that higher-income households benefit much more from the mortgage interest deduction in the U.S. tax code than lower or moderate income households.
} 
$C_{j}=\{0,1\}$ indicates whether the loan was CRA-eligible. The vector $\mathbf{X}_{j}$ contains other explanatory variables. The coefficient $\alpha$ on CRA-eligible loans captures the common reaction to CRA eligibility by both relationship and transaction lenders. On the other hand, if relationship lenders actively solicit CRA eligible loans with lower mortgage rates, we would expect mortgage spreads to be given by the alternate specification:

$\left(H_{1}\right) \quad S_{j}=f\left(\theta_{j}\right)+R_{j} f_{\lambda}\left(\theta_{j}\right)+\gamma_{\lambda} R_{j} g_{j}+\alpha C_{j}+\alpha_{\lambda} R_{j} C_{j}+\mathbf{X}_{j} \mathbf{B}+u_{j}$.

In the presence of a CRA subsidy, $\alpha_{\lambda}$ would be negative. One approach to discriminating between $\left(H_{0}\right)$ and $\left(H_{1}\right)$ is to estimate the empirical counterpart of $\left(H_{1}\right)$ and test whether the estimated coefficient $\widehat{\alpha_{\lambda}}=0$.

Because we have no good way to determine the benefit to homeownership, $g_{j}$, for any borrower, we must interpret the estimated coefficient $\widehat{\alpha_{\lambda}}$ with care. If we are willing to assume that homeownership benefit (and hence the credit-enhancing investment by relationship lenders) is uncorrelated with CRA-eligibility then we can proceed to test $\widehat{\alpha_{\lambda}}$ empirically, despite the lack of a proxy for homeownership benefit. However, it is more likely that homeownership benefit and CRAeligibility are actually negatively correlated. CRA-eligible borrowers are either lower-income, and hence benefit less from the tax code's subsidy of homeownership, or purchasing homes in lower-income neighborhoods, which may contain fewer ownership benefits (e.g. house price appreciation may be more uncertain). This effect will tend to bias $\widehat{\alpha_{\lambda}}$ down, possibly leading to a false conclusion that 
there is in fact a CRA subsidy.

On the other hand, if we are willing to assume that the homeownership benefit is completely tied to the tax code's mortgage interest deduction, we can restrict our sample to those likeliest to itemize their deductions and hence claim the mortgage interest deduction. Thus our theory suggests two identifying assumptions:

$$
E\left\{g_{j} \mid C_{j}=1\right\} \leq E\left\{g_{j} \mid C_{j}=0\right\} \text {, and: }
$$

$$
E\left\{g_{j} \mid Y_{j} \geq \bar{Y}\right\}=\bar{g}\left(Y_{j}\right), \text { all } C_{j}
$$

Here $Y_{j}$ is the borrower's income and $\bar{Y}$ is some threshold income above which we assume that that homeowners itemize their deductions. Under the first identifying assumption, $\left(I_{1}\right)$, the estimated CRA subsidy will be an upper bound on the true subsidy. Under the second identifying assumption, $\left(I_{2}\right)$, the estimated CRA subsidy will be consistent, although the intercept term for relationship lenders will be biased upward, contaminated by the function $\bar{g}(Y)$.

\section{Identifying Higher Benefit Borrowers}

Despite our identifying assumption, equation $\left(I_{2}\right)$, we do not primarily use an absolute income threshold to classify households as being higher-income; instead, we use the CRA-mandated definition of having an income of at least $120 \%$ of the MSA median income. ${ }^{19}$ Recall from our discussion of the CRA in section 2 that regulators use this definition of higher-income, and use the ratio of loans to higher-

\footnotetext{
${ }^{19}$ In section 5.4 we present results using a variety of absolute thresholds.
} 
income borrowers as one yardstick in evaluating CRA performance. Thus, households defined as higher-income by our measure will have a range of incomes; in MSAs with lower median incomes, the cutoff will be lower than in MSAs with higher median incomes. By using this MSA-dependent definition of income class we accord with CRA regulations, but at the cost that some households classified as higher-income will have incomes below those of some households classified as middle income. Figure 7 displays the empirical cumulative distribution functions of borrower income conditional on income class. As shown in the figure, the highest five percent of middle income borrowers have incomes that exceed those of the bottom quarter of higher income borrowers. However, note that all households classified as higher-income have annual incomes above $\$ 50,000$ year, and that about $90 \%$ have incomes above $\$ 60,000$. Thus, although there is some overlap between middle- and higher-income borrowers, most higher-income borrowers do have fairly high incomes.

The key issue, though, is whether these higher-income borrowers truly have a higher benefit to homeownership. Because we have identified the benefit to homeownership with the tax code's subsidy of mortgage interest (the mortgage interest deduction, or MID), we want to be sure that higher-income households (under our MSA-based definition) are actually taking advantage of the MID at a greater rate than lower- or middle-income households. To take advantage of the MID, households must itemize their deductions. Thus we can use information on the likelihood of itemizing conditional on income and quantity of mortgage debt to determine if households that we identify as higher-income are in fact using 
the MID. As explained in appendix B below, we used the Survey of Consumer Finances (SCF) to determine the probability that a household itemizes its deductions. The estimated probabilities, conditional on income and quantity of mortgage debt, are shown in figure 8 . Notice that the probability of itemizing rises sharply for households with annual incomes of around $\$ 60$ to 80,000 , and then levels off.

\subsection{Empirical Specification}

Although our theory and identification strategy provide us with an empirical specification, we present results from two alternate and simpler specifications, so that we have three primary specifications in all. In addition, we use both the standard form of CRA eligibility and an expanded form that treats the two eligibility criteria separately in each of our specifications. In all the specifications we present here, we include fixed effects for both the institution (i.e. the particular bank or mortgage company that made the loan) and the MSA.

We have a standard set of controls, which we label $X_{i}$ for observation $i$. In addition, we partition the data into two subsets, so $X_{i}=\left[\begin{array}{ll}W_{i} & Z_{i}\end{array}\right]$. We will take the subset of controls $W_{i}$ to be only those controls associated with borrower risk. A full explanation and variable names are shown in table 1. Sample means of selected variables are in table 2; tables 3, 4 and 5 present sample statistics on the loan spread, borrower income and the loan amount (mortgage size) conditional on lender type and borrower income class (higher, middle or lower).

In addition to the standard set of variables, there are four variables of partic- 
Figure 7: Empirical Cumulative Distributions Conditional on Income Class

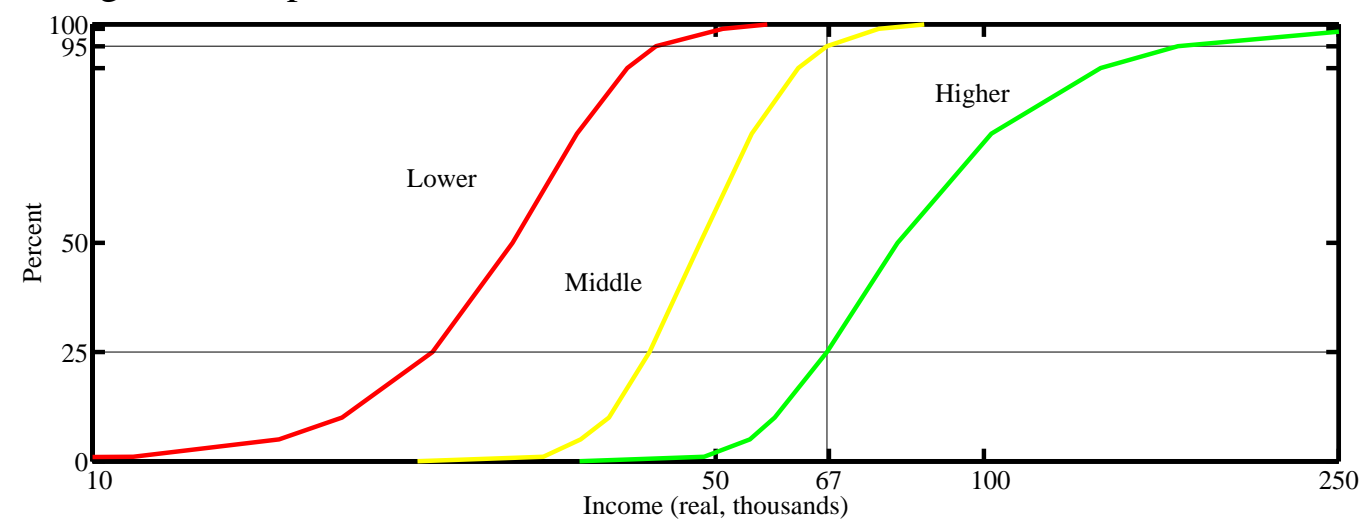

NoTE. Figure gives the empirical CDFs of borrower income, in thousands of real 1996 dollars, conditional on the borrower's income class. Income classes are defined relative to the MSA median income, so some middle-income borrowers will have incomes that exceed those of some higher-income borrowers. Table 4 presents sample statistics for borrower income.

Figure 8: Probability of Itemizing

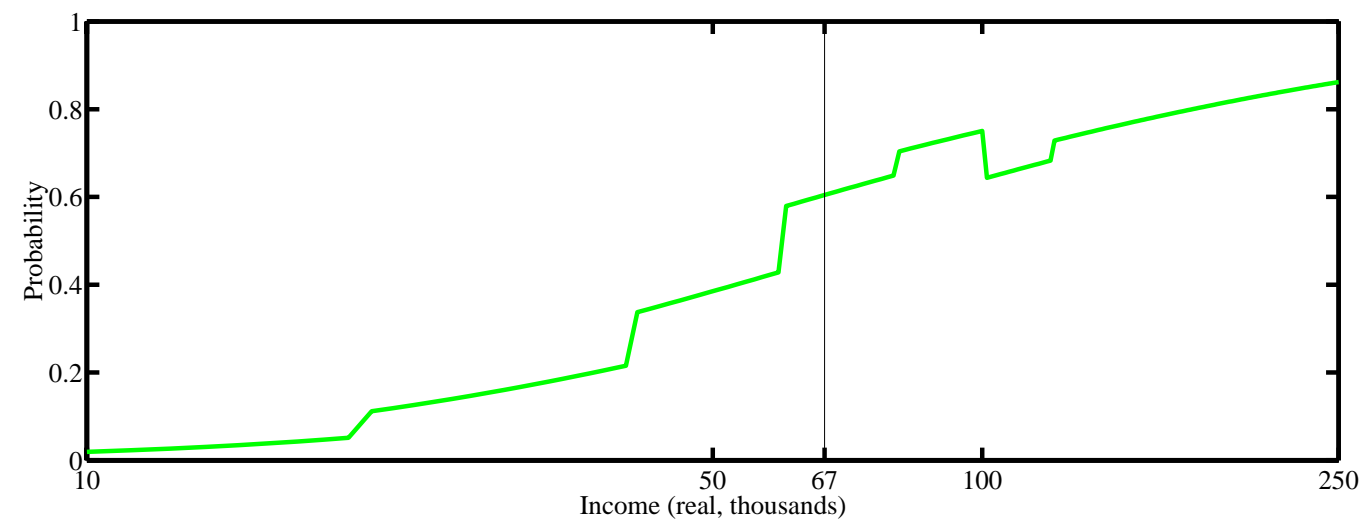

NOTE. Figure gives the probability of itemizing tax deductions conditional on income. The probability is derived from probit estimates on observations from the 1995 and 1998 waves of the Survey of Consumer Finances; see appendix B for further details. 
ular interest. First, CRA_ELIG is an indicator variable set to unity if the loan is eligible for CRA credit. This variable is comprised of the union of two other indicator variables, LOWMOD and IRLT80. The first of these, LOWMOD, indicates whether the borrower's neighborhood is lower income, which makes the loan eligible for CRA credit, regardless of the borrower's own income. The second of these, IRLT80, indicates whether the borrower's own income is below 80 percent of the median income of the MSA, in which case the loan also is eligible for CRA credit, regardless of the borrower's neighborhood. Note that CRA_ELIG and its parts do not depend on the lender type, only the borrower's characteristics.

The final variable of interest is REL_LEND. This is an indicator variable set to unity if the lender is subject to the CRA. In our theory, we identify these institutions one-for-one with relationship lenders.

We now are ready to describe our three primary specifications. In all of our regressions, the dependent variable $S_{i}$ will be the spread, in percentage points, between the effective rate on loan $i$ and the average prevailing 10-year Treasury rate in the month in which the loan was made. We label the specifications $(A)$, 
$(B)$ and $(C)$, corresponding to the equations:

$$
\begin{aligned}
S_{i}= & X_{i} B+\alpha C R A \_E L I G_{i}+\lambda R E L \_L E N D_{i}+u_{i} \\
S_{i}= & X_{i} B+\alpha C R A \_E L I G_{i}+\lambda R E L \_L E N D_{i} \\
& +\alpha_{\lambda} \text { CRA_ELIG }{ }_{i} \times R E L \_L E N D_{i}+u_{i} \\
S_{i}= & W_{i} B^{W}+Z_{i} B^{Z}+\alpha C R A \_E L I G_{i} \\
& +R E L \_L E N D_{i} \times\left[\lambda+W_{i} B_{\lambda}^{W}+\alpha_{\lambda} \text { CRA_ELIG }\right]+u_{i} .
\end{aligned}
$$

These basic regressions can be thought of as increasing in sophistication. Equation $(A)$ is the simplest regression, while equation $(B)$ expands upon the basic regression by including an interaction term between lender type and CRA eligibility. If the estimated value for $\alpha_{\lambda}$ is negative, as discussed previously, one might be tempted to conclude that relationship lenders subsidize loans to CRA eligible borrowers. Equation $(C)$, by contrast, is suggested by our theory. It is the empirical counterpart to equation $\left(H_{1}\right)$. In our model, relationship and transaction lenders react to a borrower's apparent credit risk differently, which we capture empirically by interacting the borrower's apparent risk with lender type. Depending on the identifying assumption $\left(I_{1}\right.$ or $\left.I_{2}\right)$ the estimated interaction term can have varying interpretations.

One immediate generalization that we apply to equations $(A),(B)$, and $(C)$ is to split the definition of CRA eligibility into its parts. Thus, for example, we would estimate the coefficients of an alternative version of equation $(A)$, denoted 
equation $\left(A^{\prime}\right)$ :

$$
S_{i}=X_{i} B+\alpha^{(1)} \text { LOWMOD }_{i}+\alpha^{(2)} \text { IRLT80 }_{i}+\lambda R E L \_L E N D_{i}+u_{i} .
$$

In the same way, we would estimate the extra coefficients from alternate specifications of equations $(B)$ and $(C)$ with expanded definitions of CRA eligibility; we denote these specifications as $\left(B^{\prime}\right)$ and $\left(C^{\prime}\right)$.

\subsection{Results}

Before turning to the regression results, it is instructive to consider some conditional sample means. Consider again table 3, which gives the means and standard deviations of the spreads on the mortgages in our final dataset conditional on lender type and borrower income category. For comparison's sake, the average spread between Freddie Mac's weekly published benchmark mortgage rate and the prevailing ten-year Treasury rate over the same period was about 1.5 percentage points. Notice that transaction lenders charge lower-income borrowers a higher spread than they charge other borrower types, while relationship lenders charge lower-income borrowers a lower spread than they do other bor-

rowers. For other borrower income groups, though, relationship lenders charge a slightly higher spread than do transaction lenders. Without any further investigation, we might conclude that relationship lenders are increasing spreads on non-CRA-eligible borrowers slightly in order to offer CRA-eligible borrowers attractive, low, spreads. 
We present regression coefficients for our six specifications (equations $(A)$, $(B)$ and $(C)$ with both definitions of CRA eligibility) using data from all borrowers in table 6 . Table 7 is an adjunct to table 6 ; it presents the difference in mortgage spreads for all combinations of borrower type (CRA eligible or not) and lender type (relationship or transaction) estimated under specifications $(B)$ and $\left(B^{\prime}\right)$. Figure 9 (a) presents the difference in spreads from specification $(C)$ conditional on borrower and lender type and the borrower's loan-to-value ratio.

Tables 8 and 9 and figure 9(b) present the same concepts as tables 6 and 7 and figure 9(a), except that the borrower pool is restricted to higher-income borrowers (borrowers with incomes at least 120\% of their MSA's median income).

\section{Results From Specifications $(B)$ and $\left(B^{\prime}\right)$}

As we discussed in the previous section, specifications $(B)$ and $\left(B^{\prime}\right)$ fail to capture the interaction between lender type and the borrower's credit risk and benefit to homeownership. Nevertheless, these specifications are interesting in their own right, as a starting point for our analysis.

Notice first from the columns marked $(B)$ and $\left(B^{\prime}\right)$ in tables 6 and 8 that we can reject the hypothesis that there is no interaction effect between lender type and CRA-eligibility, because the estimated interaction coefficients $\alpha_{\lambda}, \alpha_{\lambda}^{(1)}$ and $\alpha_{\lambda}^{(2)}$ are statistically different from zero; moreover, they are always negative. This can be taken as evidence of a CRA subsidy.

Tables 7 and 9 flesh out these results a bit; they show how spreads change conditional on CRA-eligibility status and lender type, relative to non-CRA-eligible 
borrowers at transaction lenders. Notice that CRA-eligible borrowers at relationship lenders generally pay the largest spreads and that non-CRA-eligible borrowers at transaction lenders the lowest. Loans at relationship lenders generally carry higher spreads for all borrower types; also, loans to CRA-eligible borrowers generally carry higher spreads at both lender types. We refer to the first difference as the relationship premium and the second as the CRA premium. The estimated interaction terms $\alpha_{\lambda}, \alpha_{\lambda}^{(1)}$ and $\alpha_{\lambda}^{(2)}$ can be decomposed into variations in these premiums, as shown in the bottom right-hand corners of tables 7 and 9. Overall, these results suggest a CRA subsidy of around seven basis points; although for borrowers who are both lower-income and purchasing houses in lower-income neighborhoods, this subsidy could rise as high as 14 basis points. This is a significant amount, equivalent in credit risk terms to dropping the loan's loan-to-value ratio from over $100 \%$ to under $80 \%$.

\section{Results From Specifications $(C)$ and $\left(C^{\prime}\right)$}

According to our theory there is an important interaction between lender type and the borrower's homeownership benefit and credit quality. Higher-risk and higher-benefit borrowers benefit more from the services provided by relationship lenders. If this were true, we would expect that the relationship premium would vary significantly by borrower credit risk.

Consider again table 6 and compare the estimated interaction terms under the pairs of columns $(B),(C)$ and $\left(B^{\prime}\right),\left(C^{\prime}\right)$. As discussed previously, the results under specifications $(B)$ and $\left(B^{\prime}\right)$ might lead one to conclude that there is a CRA 
subsidy of about seven or eight basis points. Under the specifications suggested by theory, however, the estimated interaction terms fall by at least half in absolute value. Using the simplest definition of CRA eligibility, CRA_ELIG, the estimated interaction effect drops from more than seven basis points, to just over one basis point.

The results displayed in tables 6 and 7 use the entire sample of borrowers. In this sample, identifying assumption $\left(I_{1}\right)$ seems more appropriate; in other words, the unobserved variation in homeownership benefit is negatively correlated with CRA eligibility. Thus the estimated interaction term $\alpha_{\lambda}$ is an upper bound on the actual subsidy (if any). Even this upper bound is quite small. This is strong evidence against a CRA subsidy.

Table 8 presents the same results as table 6 when we restrict the dataset to contain higher-income borrowers only. In this case, CRA eligibility is determined purely by the median income of the neighborhood where the borrower purchases his house. Our identifying assumption here, $\left(I_{2}\right)$, holds that the benefit to homeownership does not vary by neighborhood income.

Under this identifying assumption, the interaction term $\alpha_{\lambda}$ provides a consistent estimate of any CRA subsidy. However, the intercept term $\lambda$ will be biased upward by the effect of the higher benefit on mortgage rates at relationship lenders.

Comparing the columns marked $\left(B^{\prime}\right)$ and $\left(C^{\prime}\right)$ in table 8 , we see that in fact the estimated intercept term, $\widehat{\lambda}$, does increase significantly under the alternate specification. At the same time, the estimated intercept and interaction terms on 
CRA eligibility, $\widehat{\alpha}$ and $\widehat{\alpha_{\lambda}}$ fall (in absolute value). In fact, under column $\left(C^{\prime}\right), \mathrm{CRA}$ eligibility does not have a statistically significant effect on mortgage spreads at all. Thus we can reject the hypothesis of a CRA subsidy.

Our theory also makes predictions about differences in mortgage spreads conditional on lender type and borrower risk. In particular, from equation $\left(H_{0}\right)$, the difference between the spread paid by two similar borrowers at a bank and at a transaction lender is given by:

$$
E\left\{S_{i} \mid \theta, R E L \_L E N D_{i}=1, \overline{\mathbf{X}}\right\}-E\left\{S_{j} \mid \theta, R E L \_L E N D_{j}=0, \overline{\mathbf{X}}\right\}=f_{\lambda}(\theta)+\bar{\gamma} .
$$

Theory predicts that the spread difference between relationship and transaction lenders conditional on credit-worthiness, $\theta$, should be increasing in $\theta$. See figure 3 for example. Indeed, for very high-risk borrowers, it is entirely possible that borrowers will pay less at relationship lenders than at transaction lenders; as $\theta$ goes to zero, the spread at transaction lenders goes to infinity.

In figures 9(a) and 9(b) we present the empirical counterparts of equation (14). We use the coefficients estimated under specification $(C)$ in table 6 to compute the estimated difference in spreads paid by the same borrower at a relationship lender versus at a transaction lender. We hold all borrower qualities except loan-to-value (LTV) fixed. Higher values of LTV are associated with greater credit risk, and thus lower values of $\theta$.

Notice that low-LTV borrowers (presumably the safest) pay higher mortgage rates at relationship lenders while the highest-LTV borrowers (presumably the 
riskiest) pay lower spreads. This fits well with the theory developed in section 3 ; relatively safe borrowers pay more at relationship lenders than at transaction lenders while the very riskiest borrowers pay less. Indeed, the highest LTV borrowers pay large spreads at transaction lenders but not at relationship lenders. The figure also includes a separate line for CRA-eligible borrowers; this line is nearly indistinguishable from the line for non-CRA-eligible borrowers, emphasizing that the relative importance of CRA-eligibility is tiny.

Figure 9: Estimated difference in spreads between transaction and relationship lenders, by loan-to-value ratio.

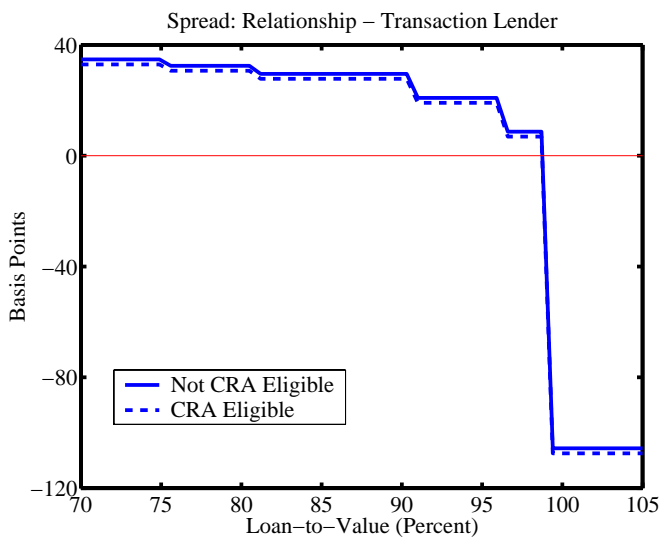

(a) All borrowers

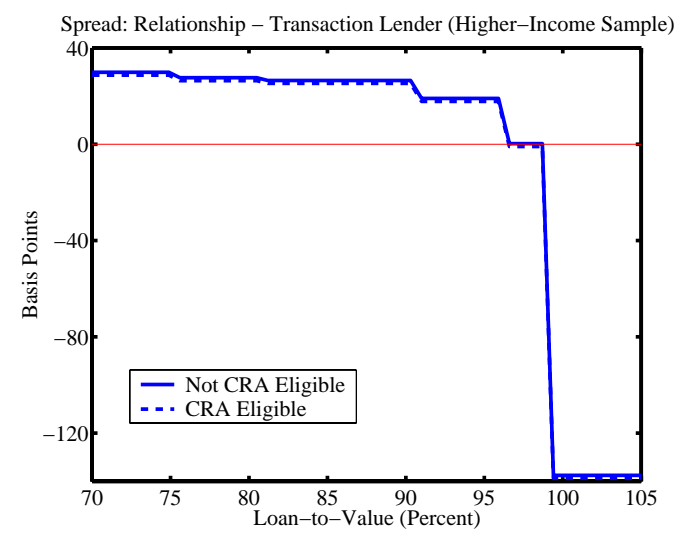

(b) Higher-income borrowers only

\subsection{Results Using Absolute Income Thresholds}

As we have discussed, until now we have classified borrowers as higher-income based on the ratio of their income to the median income in the MSA. We used this approach because CRA regulators use it; we assume that lenders are as aware of the higher-income threshold defined by their regulator as they are of the lower- 
income threshold. However, one can imagine several reasons for using an absolute income threshold to define a household as higher-income (and thus high-benefit). First, it fits better with our identifying assumption $\left(I_{2}\right)$; second, we can compute, roughly speaking, the probability that a borrower itemizes (and hence receives the MID) condition on his or her income; third, by restricting the sample to borrowers with high incomes, we might be able to control for any unobserved variation in true borrower quality.

Clearly, some of our controls are endogenous; moreover, the choice of lender type might depend on unobserved borrower-level characteristics. Until now, we have maintained the assumption that, even if there were unobserved variation in borrower credit quality, this variation was not systematic across lender types. It is possible, though, that our estimate of $\widehat{\alpha_{\lambda}}$ could be biased if lenders observe more about borrowers than we do, and if this unobserved component of credit quality varies systematically with lender type. For example, if among those households with the same apparent credit quality, the relatively lower-quality borrowers got loans from banks while the relatively higher-quality borrowers got loans from transaction lenders, we would tend to overstate the true difference in mortgage spreads. This endogenous unobserved heterogeneity in borrower types would not, by itself, affect our estimate of the CRA subsidy. However, if this self-selection were greater among borrowers eligible for CRA credit, our estimates of the of the CRA subsidy would be biased towards zero, understating the true subsidy.

One way of controlling for unobserved differences in credit quality is to restrict attention to households with high incomes. Among households with annual 
incomes greater than $\$ 100,000$, for example, there is likely to be less unobserved heterogeneity than among the general borrower population. Recall also that we include a full set of institution and MSA fixed effects. Thus we do not have to control for idiosyncratic variation in borrower quality across lenders, only within lenders.

Note that since we concentrate on relatively high-income borrowers, none will be eligible for CRA credit purely on the basis of the income test alone (in other words, none will have incomes below $80 \%$ of the MSA median income). From examining figure 8 , note that the probability of itemizing (and hence claiming the MID) rises sharply at annual incomes of between $\$ 60$ and 80 thousand. Thus we chose a series of income thresholds to bracket this critical region; in particular, we estimated our model after restricting the dataset to only those borrowers with annual incomes above $\$ 60,80,100$ or 120 thousand.

Table 10 presents sample statistics for each of the restricted samples. Notice that as borrower income grows, the average loan-to-value and loan-to-income ratios actually fall slightly, while the loan spread rises slightly. Borrowers' propensity to use relationship lenders is essentially flat, while the proportion buying houses in lower-income areas falls by about a third from the lowest to the highest income threshold. The dataset formed by eliminating those households with annual incomes below $\$ 60$ thousand contains more than 4,500 loans made to borrowers purchasing homes in lower-income neighborhoods, while the dataset formed by eliminating those households with annual incomes below $\$ 120,000$ contains only about 450 such loans. Thus although we may be controlling for borrower 
heterogeneity by increasing the threshold, we do so at the cost of statistical precision.

In table 11 we present results from our primary specification of interest, $\left(C^{\prime}\right)$, for each threshold income threshold. The estimated coefficient on the interaction term is always negative, but, again, relatively small. For the dataset formed by eliminating all borrowers with incomes below $\$ 100,000$, the point estimate indicates a subsidy of about 5.5 basis points. This is larger than the estimate from our other definition of higher-income (in table 8), but still quite small in absolute terms. Moreover, it is still smaller than the potential subsidy that we estimated in the complete dataset (from table 6).

\section{Conclusion}

We studied the effect of the Community Reinvestment Act (CRA) on mortgage lending. We developed a theory of the services provided by banks to borrowers based on their ongoing relationship with the borrower. In our model, banks compete against firms that provide only one-time financial transactions, in this case mortgages, and that do not develop a relationship with the borrower.

Using this theory, we showed that, controlling for credit risk, borrowers at banks are expected to pay more than borrowers from nonbank institutions because banks provide a costly extra service (identified as credit enhancement in our theory). Thus, the spread a borrower pays on a mortgage, we showed, depended on the borrower's credit quality and benefit to homeownership. These results suggest 
that an empirical finding that banks charge higher mortgage rates than nonbanks, but provide lower rates to CRA-eligible (lower-income) borrowers is consistent with both the view that CRA is a tax and the view that banks provide relationships that have value to their borrowers.

Our theory thus forced us to confront a serious identification issue as we attempted to discriminate between these two hypotheses. We took two approaches: (1) We assumed that the benefit to homeownership was negatively correlated with CRA eligibility; and (2) We assumed that this benefit was highest and constant for higher-income borrowers and not affected by the median income of the neighborhood. Our results under assumption (1) can be taken as an upper bound on the potential mortgage interest subsidy provoked by the CRA; while our results under assumption (2) can be taken as direct evidence of the presence or absence of a subsidy.

Under assumption (1), we found that the largest potential subsidy provided by banks in order to attract CRA eligible loans was tiny, less than six basis points in all specifications.

Under assumption (2), we restricted our sample to higher-income borrowers only; we used both the CRA criteria and a variety of absolute income thresholds to classify borrowers as higher-income. We then compared the mortgage interest rates paid by these higher-income borrowers at relationship lenders and at transaction lenders when they did or did not buy a house in a lower-income neighborhood. Those higher-income borrowers who bought homes in lower-income neighborhoods using mortgages from banks did not, in general, pay a different 
mortgage rate than other higher-income borrowers at banks. At the very most, the potential CRA-linked subsidy was less than six basis points. Thus, our second test did not find compelling evidence of a subsidy.

Our findings are consistent with the view that the CRA does not cause banks to extend mortgage loans with substantially lower mortgage rates to attract CRAeligible borrowers. However, it may still be the case that the CRA forced banks to institute costly special lending programs or otherwise pay a fixed investment in order to make loans to CRA-eligible borrowers. Beyond the effects on mortgage rates this paper does not address the overall costs or benefits of the CRA. 


\section{A Constructing the Base Dataset}

Our final dataset, as discussed in the main text, contains information on individual mortgage loans, borrowers and lenders drawn from three primary datasets: HMDA, MIRS and a PMI dataset. Further, we dropped all loans that were not 30-year and fixed-rate, and those loans made by lenders or in MSAs for whom we had relatively few observations. In this section we describe in some detail the precise nature of the statistical matching procedure used to construct the base dataset, and the effect of our restrictions on the final dataset.

\section{A.1 The Statistical Match}

Our first major step was to match the loan application register (the "LAR") from the Home Mortgage Disclosure Act records to the records from the Federal Housing Finance Board's (FHFB) Monthly Interest Rate Survey (the "MIRS"). Our second major step was to match these records to the Private Mortgage Insurer (the "PMI") records.

\section{Timing of the LAR-MIRS match}

Ideally, both the LAR and the MIRS would contain specific loan identifiers (such as borrower name or property street address) that would allow precise matches. Such identifiers are not present in either data file. Similarly, it would be desirable if both files contained precise dates with the same date concept (that is, the same definition of the day on which the mortgage is complete). Instead, MIRS dates are monthly, and the LAR and MIRS feature slightly different date concepts. The MIRS records contain a "cycle date" variable (coded, e.g., as 9601, 9602, etc for January 1996, February 1996 and so on) rather than an "action date" variable as in the LAR records. ${ }^{20}$ Information from the institution conducting the MIRS (the FHFB) led us to believe that observations are drawn mostly from the end of the cycle date month (the official documentation says the loans must close in the last five working days of the month). Thus, we matched MIRS records from one cycle date to LAR records from the middle of the cycle date month to the middle of the next month.

\section{Summary of procedure}

Our procedure can be divided into several parts. First, we prepared the LAR records, then we prepared the MIRS records, then we matched these two datasets. After that, we matched to the PMI records.

\footnotetext{
${ }^{20}$ In the case of loan originations, the action date is the closing date of the loan. The date gives the day and month.
} 
In producing the LAR dataset to prepare to match, we extracted only those HMDA LAR records that:

1. Were originations

2. Were for home purchases

3. Were conventional

4. Had a valid geocode (state, county and census tract)

5. Had a valid MSA (no "non-MSA" records)

We then calculated the cycle date for the LAR records (using the month and day of the LAR action date) and determined the ZIP codes for the LAR records. Note that LAR records may sometimes be matched to more than one ZIP code.

We then turned to the MIRS dataset. We discarded only those MIRS records with invalid or missing MSA codes.

We then matched the two databases:

1. We sorted each database by MSA, state and cycle date to produce a set of potential matches ("couplets")

2. If the ZIP codes in a couplet were not an exact match, we discarded the couplet

3. For the remaining couplets, we calculated the difference in loan amounts

4. We then sorted the couplets into groups by MSA, state, and ZIP code (the "geocode") and the cycle date

5. In each geocode-month group, we chose the first couplet (that is, the couplet with the smallest difference in loan amount) as a potential match couplet

6. The next couplet in each group (the one with the second smallest loan amount difference) was examined to see if either side had previously been matched; if so it was discarded, if not, it was the next potential match couplet

7. All potential match couplets with loan amount differences greater than $\$ 2,000$ were discarded.

At the end of this procedure we were left with a set of LAR-MIRS match couplets. In one sense, this database already contains almost all of the variables of interest. However, many of these mortgages will carry private mortgage insurance. PMI rates are (broadly speaking) set by state insurance commissions and PMI itself affects the effective interest rate on the mortgage because the payments are rolled into the mortgage's APR. About eight companies provide PMI insurance; these companies voluntarily submit a HMDA-like record to the FFIEC, which we refer to as the PMI database. ${ }^{21}$ We augmented our LARS-MIRS couplet match dataset with a further statistical match against the PMI database (the lender name is suppressed in the PMI database by the PMI companies, so we cannot do an exact

\footnotetext{
${ }^{21}$ By 2000, a merger had reduced the number of PMI companies to seven.
} 
match). Because the PMI database closely follows the HMDA database in form, we were able to match on several identifying criteria.

To prepare the PMI database for matching, we discarded all records without a valid geocode (MSA, state, county and census tract), that were attached to loans for purposes other than the purchase of a 1-4 family home, or were for an action other than loan origination. To match the resulting PMI database with our LARS-MIRS matched couplets we:

1. Sorted the PMI database by geocode (state, MSA, county and census tract) to produce the same geocode categories as in the LARS-MIRS database; this gave us our set of potential triplets

2. We then compared the "race or national origin" (RONO) codes from the LARS data and the PMI data; these had to match exactly, producing a winnowed set of potential triplets

3. For each of these potential triplets we calculate the absolute difference in three variables in the LARS and PMI data:

(a) Loan amount

(b) Borrower income

(c) Action date

4. We discarded all potential triplets in which the loan amount or borrower income differed by more than $\$ 2,000$ or in which the action date differed by more than 150 days

5. To produce the A match:

We then sorted by geocode, loan amount difference, borrower income amount difference and action date difference; for each geocode group we picked the first triplet as an actual triplet, we then checked subsequent triplets to see if either side had already matched, if so then that triplet was discarded, if not, it became an actual triplet

6. To produce the $B$ match:

We then collected all unmatched couplets and PMI records and tried to match them again using slightly different criteria; in particular, we tightened the loan amount difference to $\$ 1,000$ but widened the income amount difference to $\$ 10,000$ (on the theory that differing definitions of "income" might be affecting our match).

In the end, we simply discarded the few extra matches generated under the " $\mathrm{B}$ " matching procedure. 


\section{A.2 Evaluating Match Quality}

One might expect that the differences in loan amount would be zero; by allowing nonzero differences, we may be admitting spurious matches. However, both the PMI and the HMDA reporting guidelines call for loan amounts to be rounded to the nearest thousand; potentially, if the loan amount is close to the rounding midpoint, different institutions might report the loan amount differently. Further, the MIRS data come from a voluntary survey of institutions, who may truncate rather than round, or who may have a slightly different idea of what constitutes the loan balance, e.g. excluding certain fees rolled into the loan balance.

As mentioned in the text, we exclude all observations associated with smaller or inactive lending institutions. We have several reasons for doing so; in particular, because we include a full set of lender and MSA fixed effects, such observations will likely have little effect on our coefficient estimates anyway, and less-active lenders may be spreading their fixed costs over fewer loans. However, although we do not know the list of institutions polled by the FHFB in conducting the MIRS, we know that they are relatively large and well-established lenders. By excluding loans from smaller, less-active lenders, we are purging our dataset of spurious matches.

At each step in the matching procedure, we produced diagnostic variables that can be used to evaluate the quality of the match. In table A.1 we present summary statistics and the empirical CDF of the loan differences from each step of the match. As shown in the table, only about 36\% of HMDA-PMI matches had a difference of exactly zero; however, $90 \%$ had a loan difference of $\$ 500$ or less and only about four percent had a loan difference greater than $\$ 1,000$ (the HMDA rounding point). We allowed the HMDAPMI loan difference to be a little larger, because we were also matching on race or national original (which had to be an exact match) and borrower income (which generally had to be within $\$ 2,000$ of each; see section A.1 for more information).

\section{A.3 Other Types of Mortgages}

In this paper we have exclusively used fixed-rate mortgages with a 30-year amortization; in reality, households use a variety of amortization horizons and rate structures. Among the most popular are 15-year fixed-rate mortgages and certain types of adjustable-rate mortgages (ARMs).

Thirty-year fixed-rate mortgages have the considerable advantage of being relatively homogeneous products; the main source of variation among them is the effective rate on the mortgage. However, if CRA-eligible borrowers are steered towards these other types of mortgages, we might be missing the relevant variation in mortgage terms. This is doubly true if one lender type rather than another favors ARMs or 15-year mortgages for lower-income borrowers. 
Table A.1: Statistical match diagnostic: Loan amount differences

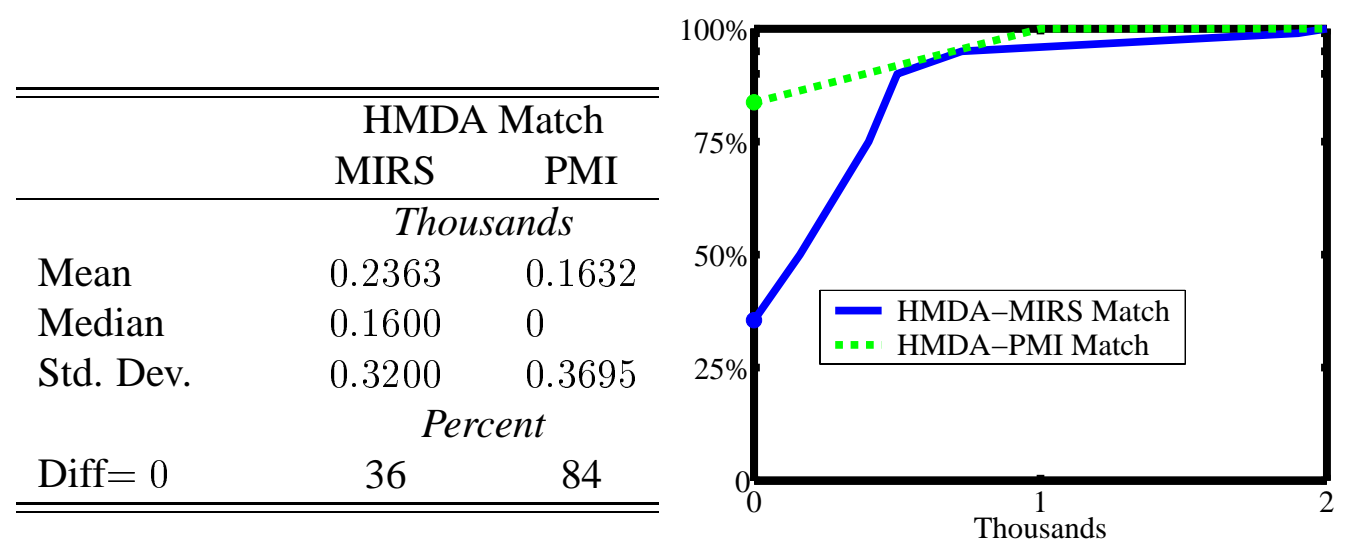

Note. Table and figure give statistics on the distribution of the difference in loan amounts from the HMDA-MIRS and the HMDA-PMI match.

Because the FHFB ask about these alternate mortgage products, we can test this proposition directly. Although we exclude ARMs and 15-year mortgages from our final dataset, we can check their relative frequency in the base dataset by lender and borrower type. Table A.2 shows the percent of observations in our base dataset that are 30-year fixed-rate mortgages conditional on borrower type, neighborhood type and lender type. The table has several interesting features: First, in all combinations of borrower, neighborhood and lender type, at most $12 \%$ of mortgages are not 30-year FRMs. Second, transaction lenders are more likely than relationship lenders to use 30-year FRMs. Third, within each lender type, there is no appreciable difference in the treatment of CRAeligible borrowers. Thus we are reassured that we are not missing an important feature of the treatment of CRA-eligible borrowers by studying 30-year FRMs exclusively. 
Table A.2: Distribution of 30-year, fixed-rate mortgages in dataset

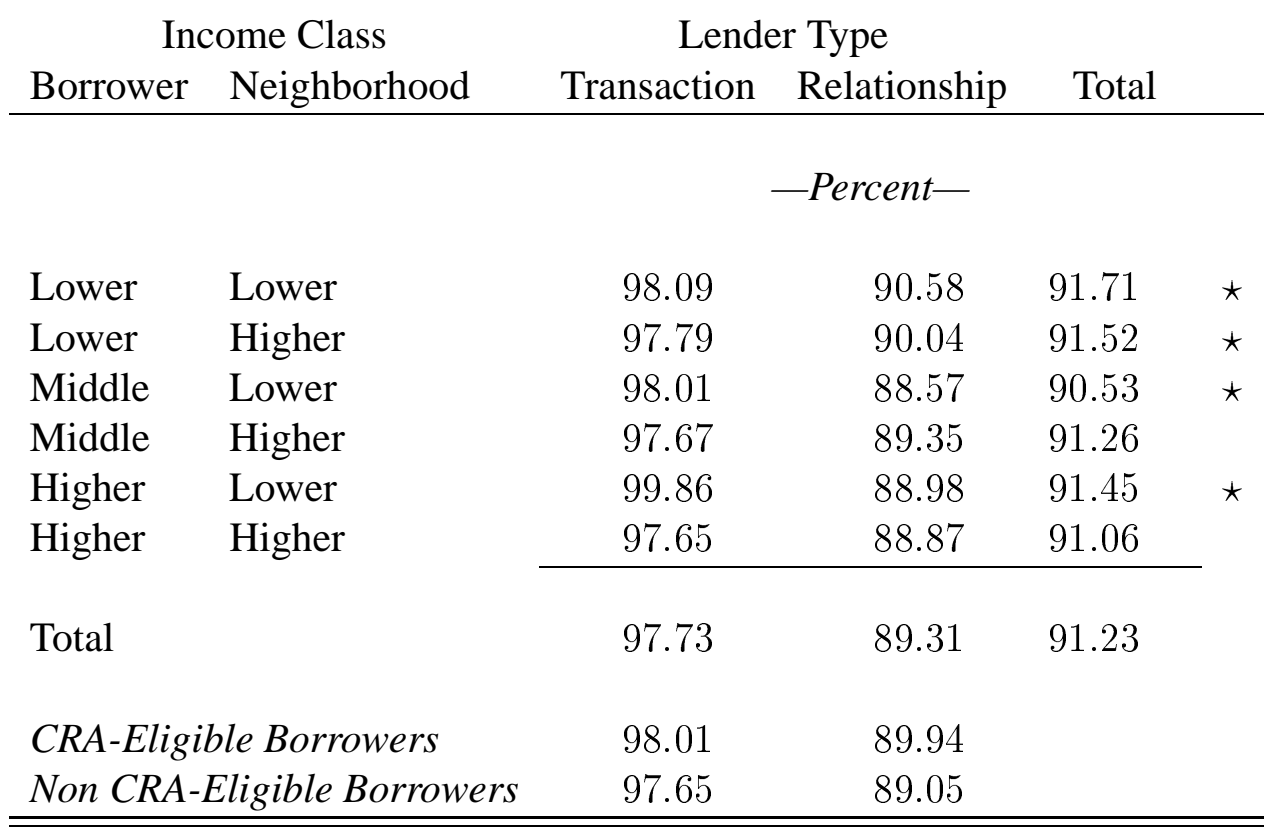

NotE. Table gives percent of loans from base dataset that are 30-year, fixed-rate by borrower and neighborhood income class. Borrower and neighborhood income classes are defined relative to the MSA median income; lower income borrowers and neighborhoods are defined as having incomes less than $80 \%$ of the MSA's median income. Middle income borrowers have incomes between $80 \%$ and $120 \%$ of the MSA median and high-income borrowers have incomes greater than or equal to $120 \%$ of the MSA median. All lower-income borrowers, regardless of neighborhood and all borrowers who purchase homes in lower-income neighborhoods, regardless of income, are eligible for CRA credit.

*: Loans eligible for CRA credit. 


\section{A.4 Results Without PMI}

As we discussed in sections A.1 and A.2, the flag variable for private mortgage insurance comes from a separate database, and hence a separate matching procedure. As with the primary match (between the HMDA and the MIRS records), this secondary match is also subject to potential error. As a robustness check, we present our results without the PMI variable. Although in the primary regressions, the PMI variable is positive and significant (as expected), eliminating it has little effect on the parameters of interest.

Table A.3: Complete Regression Results for All Borrower Types (without PMI)

\begin{tabular}{|c|c|c|c|c|c|c|}
\hline \multirow[b]{2}{*}{ Variable } & \multicolumn{6}{|c|}{ Estimated Coefficients By Regression Specification } \\
\hline & $A$ & $A^{\prime}$ & $B$ & $B^{\prime}$ & $C$ & $C^{\prime}$ \\
\hline \multicolumn{7}{|c|}{ Relationship Lender: REL_LEND } \\
\hline$\lambda$ & $\begin{array}{c}0.072 \\
(0.004)\end{array}$ & $\begin{array}{c}0.072 \\
(0.004)\end{array}$ & $\begin{array}{c}0.088 \\
(0.004)\end{array}$ & $\begin{array}{c}0.090 \\
(0.004)\end{array}$ & $\begin{array}{c}0.348 \\
(0.014)\end{array}$ & $\begin{array}{c}0.350 \\
(0.014)\end{array}$ \\
\hline \multicolumn{7}{|c|}{ CRA Eligible: CRA_ELIG } \\
\hline$\alpha$ & $\begin{array}{c}0.051 \\
(0.002)\end{array}$ & & $\begin{array}{c}0.108 \\
(0.004)\end{array}$ & & $\begin{array}{c}0.076 \\
(0.004)\end{array}$ & \\
\hline \multicolumn{7}{|c|}{ Interaction term: CRA_ELIG $\times R E L \_L E N D$} \\
\hline & & & $\begin{array}{r}-0.072 \\
(0.005)\end{array}$ & & $\begin{array}{r}-0.018 \\
(0.005)\end{array}$ & \\
\hline \multicolumn{7}{|c|}{ CRA Eligible: LOWMOD } \\
\hline$\alpha^{(1)}$ & & $\begin{array}{c}0.012 \\
(0.003)\end{array}$ & & $\begin{array}{c}0.063 \\
(0.008)\end{array}$ & & $\begin{array}{c}0.044 \\
(0.008)\end{array}$ \\
\hline $\begin{array}{l}\text { CRA Eli } \\
\alpha^{(2)}\end{array}$ & IRLT80 & $\begin{array}{c}0.051 \\
(0.002)\end{array}$ & & $\begin{array}{c}0.114 \\
(0.005)\end{array}$ & & $\begin{array}{c}0.081 \\
(0.005)\end{array}$ \\
\hline \multicolumn{7}{|c|}{ Interaction term: $L O W M O D \times R E L \_L E N D$} \\
\hline & & & & & atinued or & lext page \\
\hline
\end{tabular}


Table A.3 (continued from previous page)

Estimated Coefficients By Regression Specification (without PMI)

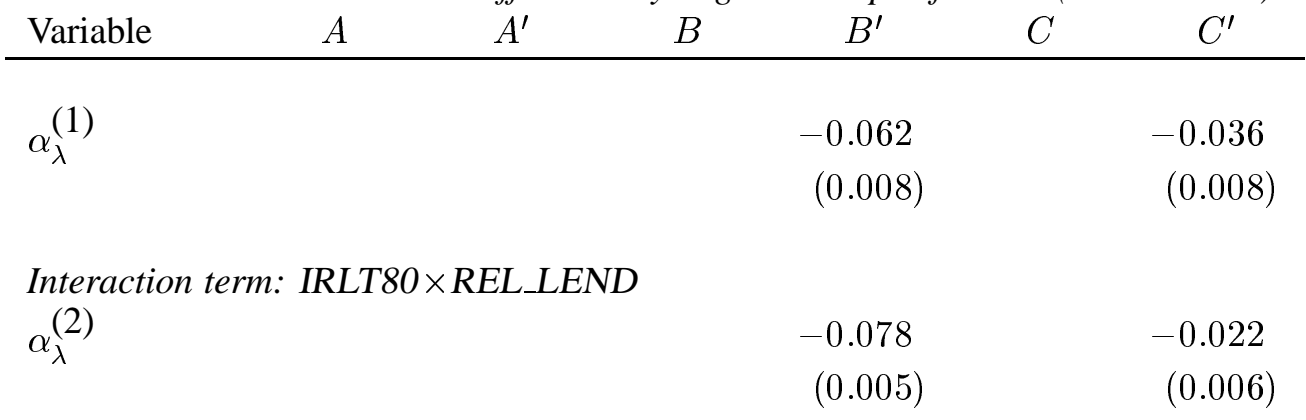

Risk Variables

Loan-to-value ratio $\nu$

$\begin{array}{lcccccc}75 \leq \nu<81 & -0.024 & -0.023 & -0.024 & -0.023 & -0.003 & -0.002 \\ & (0.002) & (0.002) & (0.002) & (0.002) & (0.005) & (0.005) \\ 81 \leq \nu<91 & 0.034 & 0.035 & 0.035 & 0.035 & 0.078 & 0.080 \\ & (0.003) & (0.003) & (0.003) & (0.003) & (0.006) & (0.006) \\ 91 \leq \nu<96 & 0.061 & 0.062 & 0.061 & 0.062 & 0.170 & 0.171 \\ & (0.003) & (0.003) & (0.003) & (0.003) & (0.005) & (0.006) \\ 96 \leq \nu<99 & 0.047 & 0.047 & 0.048 & 0.049 & 0.270 & 0.269 \\ & (0.004) & (0.004) & (0.004) & (0.004) & (0.011) & (0.011) \\ \nu \geq 99 & -0.047 & -0.046 & -0.043 & -0.041 & 1.39 & 1.24 \\ & (0.008) & (0.008) & (0.008) & (0.008) & (0.026) & (0.026)\end{array}$

Loan-to-income ratio $\ell$

$\begin{array}{lllllll}\ell & -0.067 & -0.068 & -0.068 & -0.069 & -0.032 & -0.034\end{array}$

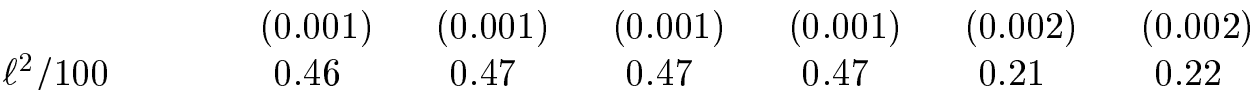

$\begin{array}{ccccccc}\ell^{2} / 100 & 0.46 & 0.47 & 0.47 & 0.47 & 0.21 & 0.22 \\ & (0.01) & (0.01) & (0.01) & (0.01) & (0.01) & (0.01)\end{array}$

$\begin{array}{lllllll}\text { FANFRED } & -0.006 & -0.006 & -0.007 & -0.007 & -0.136 & -0.136\end{array}$

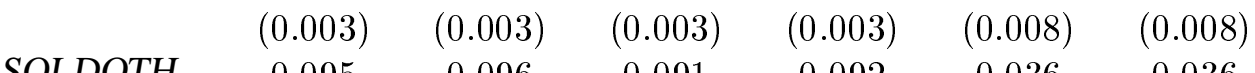

$\begin{array}{lllllll}\text { SOLDOTH } & -0.095 & -0.096 & -0.091 & -0.092 & 0.036 & 0.036\end{array}$

CONFORMSIZE

$\begin{array}{lllll}(0.004) & (0.004) & (0.004) & (0.004) & (0.010)\end{array}$ 
Table A.3 (continued from previous page)

\begin{tabular}{lcccccc}
\hline & \multicolumn{7}{c}{ Estimated } & Coefficients & \multicolumn{5}{c}{ Regression Specification (without PMI) } \\
Variable & $A$ & $A^{\prime}$ & $B$ & $B^{\prime}$ & $C$ & $C^{\prime}$ \\
\hline \multirow{4}{*}{ PMI } & -0.179 & -0.179 & -0.178 & -0.178 & 0.001 & -0.000 \\
& $(0.004)$ & $(0.004)$ & $(0.004)$ & $(0.004)$ & $(0.009)$ & $(0.009)$ \\
PCT_VAC & n.a. & n.a. & n.a. & n.a. & n.a. & n.a. \\
& & & & & & \\
& 0.013 & 0.016 & 0.013 & 0.016 & 0.033 & 0.034 \\
& $(0.005)$ & $(0.005)$ & $(0.005)$ & $(0.005)$ & $(0.011)$ & $(0.011)$
\end{tabular}

Risk Variable Interaction Terms

Loan-to-value ratio $\nu$

$75 \leq \nu<81$

$\begin{array}{cc}-0.023 & -0.023 \\ (0.006) & (0.006) \\ -0.051 & -0.051 \\ (0.007) & (0.007) \\ -0.137 & -0.137 \\ (0.006) & (0.006) \\ -0.259 & -0.256 \\ (0.012) & (0.012) \\ -1.403 & -1.401 \\ (0.027) & (0.027)\end{array}$

Loan-to-income ratio $\ell$

$\ell$

$-0.058 \quad-0.059$

$\ell^{2} / 100$

$(0.002) \quad(0.002)$

$0.80 \quad 0.81$

(0.03) (0.03)

FANFRED

$0.144 \quad 0.143$

$(0.009) \quad(0.009)$

SOLDOTH

$-0.168 \quad-0.169$

$(0.011) \quad(0.011)$

CONFORMSIZE

$-0.194 \quad-0.193$

(0.010) (0.010)

PMI

n.a. n.a. 
Table A.3 (continued from previous page)

\begin{tabular}{|c|c|c|c|c|c|c|}
\hline \multirow[b]{2}{*}{ Variable } & \multicolumn{6}{|c|}{ Estimated Coefficients By Regression Specification (without PMI) } \\
\hline & $A$ & $A^{\prime}$ & $B$ & $B^{\prime}$ & $C$ & $C^{\prime}$ \\
\hline$P C T_{-} V A C$ & & & & & $\begin{array}{c}-0.024 \\
(0.012)\end{array}$ & $\begin{array}{c}-0.021 \\
(0.012)\end{array}$ \\
\hline \multicolumn{7}{|c|}{ Other Control Variables } \\
\hline Intercept & $\begin{array}{c}2.45 \\
(0.01)\end{array}$ & $\begin{array}{c}2.45 \\
(0.01)\end{array}$ & $\begin{array}{c}2.44 \\
(0.01)\end{array}$ & $\begin{array}{c}2.44 \\
(0.01)\end{array}$ & $\begin{array}{c}2.24 \\
(0.01)\end{array}$ & $\begin{array}{c}2.24 \\
(0.01)\end{array}$ \\
\hline CLOANS & $\begin{array}{c}-0.071 \\
(0.007)\end{array}$ & $\begin{array}{r}-0.075 \\
(0.007)\end{array}$ & $\begin{array}{r}-0.072 \\
(0.007)\end{array}$ & $\begin{array}{c}-0.075 \\
(0.007)\end{array}$ & $\begin{array}{c}-0.068 \\
(0.007)\end{array}$ & $\begin{array}{c}-0.071 \\
(0.007)\end{array}$ \\
\hline LENDERS & $\begin{array}{c}0.165 \\
(0.024)\end{array}$ & $\begin{array}{c}0.176 \\
(0.024)\end{array}$ & $\begin{array}{c}0.167 \\
(0.024)\end{array}$ & $\begin{array}{c}0.177 \\
(0.024)\end{array}$ & $\begin{array}{c}0.149 \\
(0.024)\end{array}$ & $\begin{array}{c}0.160 \\
(0.024)\end{array}$ \\
\hline \multicolumn{7}{|c|}{ Year Dummies } \\
\hline YR95 & $\begin{array}{r}-0.507 \\
(0.005)\end{array}$ & $\begin{array}{c}-0.508 \\
(0.005)\end{array}$ & $\begin{array}{c}-0.506 \\
(0.005)\end{array}$ & $\begin{array}{c}-0.507 \\
(0.005)\end{array}$ & $\begin{array}{c}-0.511 \\
(0.005)\end{array}$ & $\begin{array}{r}-0.512 \\
(0.005)\end{array}$ \\
\hline YR96 & $\begin{array}{c}-0.662 \\
(0.005)\end{array}$ & $\begin{array}{c}-0.663 \\
(0.005)\end{array}$ & $\begin{array}{c}-0.661 \\
(0.005)\end{array}$ & $\begin{array}{c}-0.662 \\
(0.005)\end{array}$ & $\begin{array}{c}-0.662 \\
(0.005)\end{array}$ & $\begin{array}{c}-0.663 \\
(0.005)\end{array}$ \\
\hline YR97 & $\begin{array}{c}-0.665 \\
(0.005)\end{array}$ & $\begin{array}{c}-0.666 \\
(0.005)\end{array}$ & $\begin{array}{c}-0.665 \\
(0.005)\end{array}$ & $\begin{array}{c}-0.666 \\
(0.005)\end{array}$ & $\begin{array}{c}-0.669 \\
(0.005)\end{array}$ & $\begin{array}{r}-0.670 \\
(0.005)\end{array}$ \\
\hline YR98 & $\begin{array}{c}-0.368 \\
(0.004)\end{array}$ & $\begin{array}{r}-0.368 \\
(0.004)\end{array}$ & $\begin{array}{r}-0.367 \\
(0.004)\end{array}$ & $\begin{array}{c}-0.368 \\
(0.004)\end{array}$ & $\begin{array}{c}-0.374 \\
(0.004)\end{array}$ & $\begin{array}{r}-0.375 \\
(0.004)\end{array}$ \\
\hline YR99 & $\begin{array}{c}-0.366 \\
(0.003)\end{array}$ & $\begin{array}{c}-0.366 \\
(0.003)\end{array}$ & $\begin{array}{c}-0.366 \\
(0.003)\end{array}$ & $\begin{array}{c}-0.366 \\
(0.003)\end{array}$ & $\begin{array}{c}-0.367 \\
(0.003)\end{array}$ & $\begin{array}{c}-0.367 \\
(0.003)\end{array}$ \\
\hline \multicolumn{7}{|c|}{ POSTRUSSIA } \\
\hline & $\begin{array}{c}0.238 \\
(0.002)\end{array}$ & $\begin{array}{c}0.238 \\
(0.002)\end{array}$ & $\begin{array}{c}0.238 \\
(0.002)\end{array}$ & $\begin{array}{c}0.238 \\
(0.002)\end{array}$ & $\begin{array}{c}0.237 \\
(0.002)\end{array}$ & $\begin{array}{c}0.237 \\
(0.002)\end{array}$ \\
\hline F-Value & 102.08 & 102.20 & 101.57 & 101.57 & 95.78 & 95.96 \\
\hline $\operatorname{Pr}>\mathrm{F}$ & $<0.001$ & $<0.001$ & $<0.001$ & $<0.001$ & $<0.001$ & $<0.001$ \\
\hline $\begin{array}{l}R^{2} \\
\text { Sample Size }\end{array}$ & 0.32 & 0.32 & 0.33 & $\begin{array}{c}0.33 \\
250,593\end{array}$ & 0.34 & 0.34 \\
\hline
\end{tabular}

NOTE. Table gives selected regression coefficients and standard errors (in parentheses) from OLS regressions of the spread on a mortgage against the specified variables; see discussion in text and equations $(A),(B)$ and $(C)$ for more details. In these regressions, the PMI variable was not used. All regressions contained a full set of MSA and lending institution dummies; the F-statistic from a test of the hypothesis that all dummies were jointly equal to zero is shown. 


\section{B Probability of Itemizing Tax Deductions}

We used the 1995 and 1998 waves of the SCF to calculate the probability of itemizing tax deductions conditional on outstanding mortgage debt and income. We computed the (weighted) sample probabilities and estimated a probit model of itemization. Table B.1 presents weighted sample statistics; note that we eliminated households in which the head was younger than 25 or older than 61 . In addition, we eliminated households with annual reported total incomes that were negative, zero or above one million dollars (in real 1996 dollars). In our remaining sample, about one third of all households reported itemizing their deductions. However, this conceals significant variation. We split the sample into three parts conditional on the household's ratio of mortgage debt to income. First, those households with zero mortgage debt (and hence a ratio of zero) and then, among those households with positive mortgage debt, those above and below the median ratio of 1.03. As shown in table B.1, among those with zero debt, the itemization rate is about 12 percent, while among those households with positive mortgage debt, the itemization rate is around 50 percent.

In table B. 2 we present the (weighted) tax deduction itemization rate conditional on income range and mortgage debt. Although the itemization rate rises with income for all households, it rises sharpest for those with positive mortgage debt. Beyond $\$ 60$ or 80 thousand the itemization rate largely levels off among households with mortgages, while it continues to rise among those without. About $80 \%$ of households with positive mortgage debt and incomes greater than $\$ 80,000$ itemize their deductions (although this rate does bounce around a bit).

A parametric approach is to estimate a probit model of the probability of itemizing. Because we are particularly interested in how this probability reacts to income, we include a general specification of income (a set of dummies as well as the more traditional log income). The coefficient estimates are shown in B.3. Figure 8 presents the results graphically; in the figure all variables except income are set to their conditional means for each income range. The results indicate that, as in the non-parametric approach, above about \$60-80 thousand per year of income, the probability of itemizing largely levels off. 
Table B.1: SCF Sample Statistics

\begin{tabular}{|c|c|c|c|}
\hline \multirow[b]{2}{*}{ Variable } & \multicolumn{3}{|c|}{$\begin{array}{c}\text { Mortgage Debt to Income Ratio } \\
\text { Median }\end{array}$} \\
\hline & Zero & Below & Above \\
\hline Mortgage Debt ${ }^{a}$ & & $\begin{array}{c}43.16 \\
(47.69)\end{array}$ & $\begin{array}{c}99.33 \\
(84.54)\end{array}$ \\
\hline Income $^{a}$ & $\begin{array}{c}35.40 \\
(43.87)\end{array}$ & $\begin{array}{c}84.28 \\
(93.88)\end{array}$ & $\begin{array}{c}54.15 \\
(40.48)\end{array}$ \\
\hline $\mathrm{Age}^{b}$ & $\begin{array}{c}40.71 \\
(10.44)\end{array}$ & $\begin{array}{l}44.73 \\
(8.70)\end{array}$ & $\begin{array}{l}41.25 \\
(9.12)\end{array}$ \\
\hline & & -Percent & \\
\hline Itemize & 12.42 & 53.33 & 52.32 \\
\hline Second Mortgage & 1.8 & 12.37 & 12.72 \\
\hline High School Degree & 56.04 & 54.84 & 52.87 \\
\hline College Degree & 24.59 & 34.64 & 38.88 \\
\hline $1995 \mathrm{SCF}$ & 49.31 & 48.36 & 47.08 \\
\hline Observations & 2,649 & 1,489 & 1,486 \\
\hline
\end{tabular}

NotE. Table gives weighted sample statistics from the combined 1995 and 1998 waves of the Survey of Consumer Finances. Sample is broken into three parts conditional on the mortgage-to-income ratio: Those with zero mortgage debt (and hence a ratio of zero) and, among those with positive mortgage debt, those above and those below the median of 1.03.

\footnotetext{
${ }^{a}$ In thousands of real 1996 dollars.

${ }^{b}$ Age of household head.
} 
Table B.2: Conditional Probability of Itemizing Deductions

\begin{tabular}{|c|c|c|c|}
\hline \multirow[b]{2}{*}{ Income Range } & \multirow[b]{2}{*}{ Zero } & \multicolumn{2}{|c|}{$\begin{array}{c}\text { to Income Ratio } \\
\text { Median }\end{array}$} \\
\hline & & Below & Above \\
\hline Income $\leq 20$. & 0.02 & 0.00 & 0.14 \\
\hline $20<$ Income $\leq 40$. & 0.09 & 0.25 & 0.37 \\
\hline $40<$ Income $\leq 60 \ldots$ & 0.21 & 0.44 & 0.52 \\
\hline $60<$ Income $\leq 80$. & 0.28 & 0.66 & 0.79 \\
\hline $80<$ Income $\leq 100 \ldots$ & 0.40 & 0.74 & 0.84 \\
\hline $100<$ Income $\leq 120$ & 0.54 & 0.61 & 0.77 \\
\hline Income $>120 \ldots \ldots$ & 0.61 & 0.87 & 0.81 \\
\hline
\end{tabular}

NOTE. Table gives weighted incidence of tax itemization conditional on income range and the ratio of mortgage debt to income; data are from the 1995 and 1998 waves of the SCF. 
Table B.3: Probit Results of Tax Itemization Model

\begin{tabular}{|c|c|}
\hline Variable & Estimated Coefficient \\
\hline Income Class Dummy Variables & \\
\hline $20<$ Income $\leq 40 \ldots \ldots \ldots \ldots$ & $\begin{array}{c}0.17 \\
(0.12)\end{array}$ \\
\hline $40<$ Income $\leq 60$ & $\begin{array}{c}0.32 \\
(0.16)\end{array}$ \\
\hline $60<$ Income $\leq 80$ & $\begin{array}{c}0.61 \\
(0.19)\end{array}$ \\
\hline $80<$ Income $\leq 100$ & $\begin{array}{c}0.68 \\
(0.22)\end{array}$ \\
\hline $100<$ Income $\leq 120$ & $\begin{array}{c}0.37 \\
(0.26)\end{array}$ \\
\hline Income $>120$ & $\begin{array}{c}0.47 \\
(0.30)\end{array}$ \\
\hline Log income........ & $\begin{array}{c}0.66 \\
(0.11)\end{array}$ \\
\hline Zero Mortgage Debt $\ldots \ldots \ldots \ldots \ldots \ldots \ldots \ldots$ & $\begin{array}{c}-0.73 \\
(0.05)\end{array}$ \\
\hline Second Mortgage Present ................. & $\begin{array}{c}0.37 \\
(0.07)\end{array}$ \\
\hline (Mortgage Debt Level)/(100,000) ...... & $\begin{array}{c}0.11 \\
(0.04)\end{array}$ \\
\hline Age..... & $\begin{array}{c}0.03 \\
(0.02)\end{array}$ \\
\hline $\mathrm{Age}^{2}$. & $\begin{array}{c}-0.02 \\
(0.02)\end{array}$ \\
\hline $\begin{array}{l}\text { Highest Diploma Achieved } \\
\text { High School Degree....... }\end{array}$ & $\begin{array}{c}-0.16 \\
(0.07)\end{array}$ \\
\hline & continued on next page \\
\hline
\end{tabular}


Table B.3 (continued from previous page)

\begin{tabular}{lc}
\hline Variable & Estimated Coefficient \\
\hline College Degree $\ldots \ldots \ldots \ldots \ldots \ldots \ldots \ldots \ldots \ldots \ldots \ldots \ldots \ldots$ & -0.23 \\
& $(0.08)$ \\
Observation from 1995 SCF ................... & 0.03 \\
\end{tabular}

NotE. Table gives coefficient estimates and standard errors for a probit regression. The dependent variable was an indicator set to unity if the household head itemized his or her deductions in the previous tax year. 


\section{References}

Acemoglu, D. and J. D. Angrist (2001). Consequences of employment protection? The case of the Americans with Disabilities Act. Journal of Political Economy 109(5), 915-57.

Avery, R., R. Bostic, and G. B. Canner (2002). Assessing the CRA's necessity and efficiency. Manuscript, Federal Reserve Board, Washington DC.

Avery, R. B., R. W. Bostic, and G. B. Canner (2000). CRA special lending programs. Federal Reserve Bulletin 86(11), 711-31.

Board of Governors of the Federal Reserve System (1993). Report to the Congress on Community Development Lending by Depository Institutions. Washington, DC: Federal Reserve Board.

Board of Governors of the Federal Reserve System (2000). Report on the Performance and Profitability of CRA-related Lending. Washington, DC: Federal Reserve Board.

Bolton, P. and X. Freixas (2000). Equity, bonds, and bank debt: Capital structure and financial market equilibrium under asymmetric information. Journal of Political Economy 108(2), 324-51.

Boot, A. W. A. and A. V. Thakor (1997). Financial system architecture. Review of Financial Studies 10(3), 693-733.

Boot, A. W. A. and A. V. Thakor (2000). Can relationship banking survive competition? The Journal of Finance 55(2), 679-713.

Brady, P., J.-A. Cronin, and S. Houser (2001). Regional differences in the utilization of the mortgage interest deduction. Office of Tax Analysis Working Paper 88, U.S. Department of the Treasury.

Canner, G. B. and W. Passmore (1995a). Credit risk and the provision of mortgages to lower-income and minority homebuyers. Federal Reserve Bulletin 81(11), 989-1016.

Canner, G. B. and W. Passmore (1995b). Home purchase lending in lowincome neighborhoods and to low-income borrowers. Federal Reserve Bulletin 81(2), 71-103.

Canner, G. B. and W. Passmore (1996). The relative profitability of commercial banks active in lending in lower-income neighborhoods and to lowerincome borrowers. In Proceedings of the 32nd Annual Conference on Bank Structure and Competition. Federal Reserve Bank of Chicago. 
Canner, G. B., W. Passmore, and B. Surette (1996). Distribution of credit risk among providers of mortgages to lower-income and minority homebuyers. Federal Reserve Bulletin 82(12), 1077-1101.

Carey, M., M. Post, and S. A. Sharpe (1998). Does corporate lending by banks and finance companies differ? Evidence on specialization in private debt contracting. The Journal of Finance 53(3), 845-78.

Chemmanur, T. J. and P. Fulghieri (1994). Reputation, renegotiation, and the choice between bank loans and publicly traded debt. Review of Financial Studies 7(3), 475-506.

Evanoff, D. D. and L. M. Segal (1996). CRA and fair lending regulations: Resulting trends in mortgage lending. Federal Reserve Bank of Chicago Economic Perspectives 20(6), 19-46.

Evanoff, D. D. and L. M. Segal (1997). Strategic responses to bank regulation: Evidence from HMDA data. Journal of Financial Services Research 11(12), 69-93.

Garwood, G. L. and D. S. Smith (1993). The community reinvestment act: Evolution and current issues. Federal Reserve Bulletin 79(4), 251-67.

Harvey, K. D., M. C. Collins, P. Nigro, and B. Robinson (2001). Disparities in mortgage lending, bank performance, economic influence, and regulatory oversight. Journal of Real Estate Finance and Economics 23, 379-410.

Henderson, J. V. and Y. M. Ioannides (1983). A model of housing tenure choice. American Economic Review 73(1), 98-113.

Lehnert, A. and D. M. Maki (2002). Consumption, debt, and portfolio choice: Testing the effects of bankruptcy law. Manuscript, Federal Reserve Board of Governors, Washington, DC.

Levitt, S. D. (1997). Using electoral cycles in police hiring to estimate the effect of police on crime. American Economic Review 87(3), 270-290.

Levitt, S. D. (1998). Juvenile crime and punishment. Journal of Political Economy 106(6), 1156-1185.

Malmquist, D., F. Phillips-Patrick, and C. Rossi (1997). The economics of lowincome mortgage lending. Journal of Financial Services Research 11(1-2), $169-88$. 
Meeker, L. and F. Myers (1996). Community Reinvestment Act Lending: Is it profitable? In Financial Industry Perspectives 1996, pp. 13-35. Kansas City, MO: Federal Reserve Bank of Kansas City.

Pence, K. (2001). Foreclosing on opportunity? State laws and mortgage credit. Manuscript, Federal Reserve Board, Washington DC.

Sharpe, S. A. (1997). The effect of consumer switching costs on prices: A theory and its application to the bank deposit market. Review of Industrial Organization 12(1), 79-94.

Zinman, J. (2002). The causes and real effects of credit constraints: Evidence from the community reinvestment act. Manuscript, M.I.T. Department of Economics, Cambridge MA. 
Table 1: Control Variable Names and Definitions

\begin{tabular}{|c|c|c|}
\hline & Name & Definition \\
\hline \multicolumn{3}{|r|}{ Risk Variables } \\
\hline$w$ & LTVBTW7581 & Loan to value ratio $(\nu)$ between $75 \%$ and $80 \%$ \\
\hline$w$ & LTVBTW8191 & Loan to value ratio $(\nu)$ between $81 \%$ and $90 \%$ \\
\hline$w$ & LTVBTW9196 & Loan to value ratio $(\nu)$ between $91 \%$ and $95 \%$ \\
\hline$w$ & LTVBTW9699 & Loan to value ratio $(\nu)$ between $96 \%$ and $98 \%$ \\
\hline$w$ & LTVGTEQ99 & Loan to value ratio $(\nu)$ greater than or equal to $99 \%$ \\
\hline$w$ & LOANINC & Loan to income ratio (also denoted $\ell$ ) \\
\hline$w$ & LOANINCSQ & Loan to income ratio squared $\left(\ell^{2}\right)$ \\
\hline$w$ & FANFRED & Loan sold to Fannie Mae or Freddie Mac \\
\hline$w$ & SOLDOTH & Loan sold to another securitizer \\
\hline$w$ & CONFORMSIZE & Loan size is within the conforming loan limit \\
\hline$w$ & $P M I$ & Loan carries private mortgage insurance \\
\hline$w$ & $P C T_{-} V A C$ & $\begin{array}{l}\text { Synthetic variable combining information on percent } \\
\text { of dwellings vacant and percent boarded up. }\end{array}$ \\
\hline & & Other Control Variables \\
\hline$z$ & CLOANS & $\begin{array}{l}\text { Number of conventional home purchase loans made } \\
\text { in the same calendar year and in the same census } \\
\text { tract, divided by the number of } 1-4 \text { family units in } \\
\text { the tract }\end{array}$ \\
\hline$z$ & LENDERS & $\begin{array}{l}\text { Number of different lenders making loans in the tract } \\
\text { in the calendar year, divided by the number of } 1-4 \\
\text { family units in the tract }\end{array}$ \\
\hline$z$ & $Y R x x$ & Year dummies \\
\hline$z$ & NAMEXXX & Institution dummies \\
\hline$z$ & $\operatorname{MSAxxx}$ & MSA dummies \\
\hline
\end{tabular}

Note. Table gives names, definitions, and categories of the standard control variables used in the regressions. A designation of $w$ indicates that the variable is associated with a borrower's credit risk, while a designation of $z$ indicates that the variable is associated with other factors affecting mortgage spreads. 
Table 2: Sample Means of Selected Variables

\begin{tabular}{|c|c|c|c|}
\hline Variable & \multicolumn{3}{|c|}{ Lender Type } \\
\hline Mortgage spread & $\begin{array}{c}1.85 \\
(0.51)\end{array}$ & $\begin{array}{c}1.85 \\
(0.52)\end{array}$ & $\begin{array}{c}1.87 \\
(0.49)\end{array}$ \\
\hline Loan Amount ${ }^{a}$ & $\begin{array}{l}126.43 \\
(66.09)\end{array}$ & $\begin{array}{l}124.22 \\
(65.13)\end{array}$ & $\begin{array}{l}134.01 \\
(68.72)\end{array}$ \\
\hline Loan-to-value ratio $(\nu)$ & $\begin{array}{c}82.05 \\
(14.51)\end{array}$ & $\begin{array}{c}81.93 \\
(14.78)\end{array}$ & $\begin{array}{c}82.47 \\
(13.54)\end{array}$ \\
\hline \multirow[t]{2}{*}{ Loan-to-income ratio $(\ell)$} & $\begin{array}{c}2.15 \\
(1.24)\end{array}$ & $\begin{array}{c}2.14 \\
(0.87)\end{array}$ & $\begin{array}{c}2.06 \\
(2.06)\end{array}$ \\
\hline & & -Percent- & \\
\hline FANFRED & 70.5 & 67.1 & 82.4 \\
\hline SOLDOTH & 11.8 & 11.5 & 12.7 \\
\hline CONFORMSIZE & 93.8 & 94.3 & 91.9 \\
\hline PMI & 36.3 & 39.2 & 26.2 \\
\hline$P C T_{-} V A C$ & 3.1 & 3.3 & 2.5 \\
\hline CRA_ELIG & 28.0 & 29.5 & 22.6 \\
\hline LOWMOD & 8.1 & 8.6 & 6.1 \\
\hline IRLT80 & 23.9 & 25.4 & 18.8 \\
\hline Observations & 250,593 & 193,827 & 56,766 \\
\hline
\end{tabular}

Note. Table gives means and standard deviations (in parentheses) of selected variables for the indicated subsets of the data. Relationship lenders are defined as commercial banks and savings institutions; transaction lenders are defined as independent mortgage bankers.

\footnotetext{
${ }^{a}$ In thousands of real, 1996, dollars.
} 
Table 3: Mean and Standard Deviation of Mortgage Spread Conditional On Borrower Income and Lender Type

\begin{tabular}{|c|c|c|c|}
\hline & \multicolumn{3}{|c|}{$\overline{\text { Lender Type }}$} \\
\hline & Relationship & Transaction & All \\
\hline & \multicolumn{3}{|c|}{ Lower-Income Borrowers: } \\
\hline & \multicolumn{3}{|c|}{ Income $<80 \%$ of MSA Median } \\
\hline Spread Mean & 1.7818 & 1.8963 & 1.8023 \\
\hline Spread Std. Dev. & $(0.5950)$ & $(0.5142)$ & $(0.5830)$ \\
\hline \multirow[t]{3}{*}{ Observations } & 49,174 & 10,700 & 59,874 \\
\hline & \multirow{2}{*}{\multicolumn{3}{|c|}{$\begin{array}{c}\text { Medium-Income Borrowers: } \\
80 \% \leq \text { Income }<120 \% \text { of MSA Median }\end{array}$}} \\
\hline & & & \\
\hline Spread Mean & 1.8584 & 1.8567 & 1.8580 \\
\hline Spread Std. Dev. & $(0.4937)$ & $(0.4861)$ & $(0.4920)$ \\
\hline \multirow[t]{3}{*}{ Observations } & 55,198 & 16,086 & 71,284 \\
\hline & \multirow{2}{*}{\multicolumn{3}{|c|}{$\begin{array}{c}\text { Higher-Income Borrowers: } \\
\text { Income } \geq 120 \% \text { of MSA Median }\end{array}$}} \\
\hline & & & \\
\hline Spread Mean & 1.8788 & 1.8680 & 1.8761 \\
\hline Spread Std. Dev. & $(0.4861)$ & $(0.4850)$ & $(0.4858)$ \\
\hline \multirow[t]{2}{*}{ Observations } & 89,455 & 29,980 & 119,435 \\
\hline & \multicolumn{3}{|c|}{ All Income Categories } \\
\hline Spread Mean & 1.8484 & 1.8702 & 1.8533 \\
\hline Spread Std. Dev. & $(0.5194)$ & $(0.4911)$ & $(0.5133)$ \\
\hline Observations & 193,827 & 56,766 & 250,593 \\
\hline
\end{tabular}

NotE. Table gives means and standard deviations of the spreads (effective rate minus prevailing ten-year Treasury rate) on mortgages conditional on borrower income and lender type, as well as the number of observations in each cell. Note that loans to lower-income borrowers are always eligible for CRA credit; loans to other types of borrowers are only eligible for CRA credit if the purchased home is in a lower-income neighborhood. 
Table 4: Borrower income conditional on class

\begin{tabular}{lcc}
\hline \hline Borrower income class & Mean & Median \\
\hline All borrower income classes $\ldots \ldots \ldots \ldots \ldots \ldots \ldots \ldots$ & 65.21 & 56.31 \\
& $(54.07)$ & \\
Lower: income $\leq 80 \%$ of MSA median) $\ldots \ldots \ldots \ldots \ldots$ & 29.58 & 29.59 \\
& $(8.19)$ & \\
Middle: $80 \%<$ income $<120 \%$ of MSA median $\ldots \ldots \ldots$ & 49.11 & 48.04 \\
& $(9.50)$ & \\
Higher: income $\geq 120 \%$ of MSA median $\ldots \ldots \ldots \ldots \ldots$ & 92.69 & 80.00 \\
& $(67.09)$ & \\
\hline \hline
\end{tabular}

NOTE. Table gives mean and median incomes (in thousands of real 1996 dollars) of borrowers in the dataset by income class; standard deviations are in parentheses.

Table 5: Loan Amount Conditional on Lender and Borrower Type

\begin{tabular}{|c|c|c|c|}
\hline \multirow[b]{2}{*}{ Borrower income class } & \multicolumn{3}{|c|}{ Lender Type } \\
\hline & All & Relationship & Transaction \\
\hline All. & $\begin{array}{l}126.43 \\
(66.09)\end{array}$ & $\begin{array}{c}124.22 \\
(65.13)\end{array}$ & $\begin{array}{c}134.01 \\
(68.72)\end{array}$ \\
\hline Lower. & $\begin{array}{c}76.39 \\
(31.65)\end{array}$ & $\begin{array}{c}75.30 \\
(30.98)\end{array}$ & $\begin{array}{c}81.40 \\
(34.11)\end{array}$ \\
\hline Middle & $\begin{array}{l}110.53 \\
(40.47)\end{array}$ & $\begin{array}{l}109.88 \\
(40.43)\end{array}$ & $\begin{array}{c}112.78 \\
(40.55)\end{array}$ \\
\hline Higher ......... & $\begin{array}{l}161.01 \\
(71.29)\end{array}$ & $\begin{array}{l}159.95 \\
(70.25)\end{array}$ & $\begin{array}{l}164.18 \\
(74.20)\end{array}$ \\
\hline
\end{tabular}

NOTE. Table gives means and standard deviations of the mortgage amount in thousands of real 1996 dollars conditional on lender type and borrower income class. 
Table 6: Complete Regression Results for All Borrower Types

\begin{tabular}{|c|c|c|c|c|c|c|}
\hline \multirow[b]{2}{*}{ Variable } & \multicolumn{6}{|c|}{ Estimated Coefficients By Regression Specification } \\
\hline & $A$ & $A^{\prime}$ & $B$ & $B^{\prime}$ & $C$ & $C^{\prime}$ \\
\hline \multicolumn{7}{|c|}{ Relationship Lender: REL_LEND } \\
\hline$\lambda$ & $\begin{array}{c}0.070 \\
(0.004)\end{array}$ & $\begin{array}{c}0.070 \\
(0.004)\end{array}$ & $\begin{array}{c}0.085 \\
(0.004)\end{array}$ & $\begin{array}{c}0.088 \\
(0.004)\end{array}$ & $\begin{array}{c}0.347 \\
(0.014)\end{array}$ & $\begin{array}{c}0.349 \\
(0.014)\end{array}$ \\
\hline \multicolumn{7}{|c|}{ CRA Eligible: CRA_ELIG } \\
\hline$\alpha$ & $\begin{array}{c}0.051 \\
(0.002)\end{array}$ & & $\begin{array}{c}0.108 \\
(0.004)\end{array}$ & & $\begin{array}{c}0.076 \\
(0.004)\end{array}$ & \\
\hline \multicolumn{7}{|c|}{ Interaction term: $C R A \_E L I G \times R E L \_L E N D$} \\
\hline$\alpha_{\lambda}$ & & & $\begin{array}{r}-0.072 \\
(0.005)\end{array}$ & & $\begin{array}{r}-0.018 \\
(0.005)\end{array}$ & \\
\hline \multicolumn{7}{|c|}{ CRA Eligible: LOWMOD } \\
\hline$\alpha^{(1)}$ & & $\begin{array}{c}0.012 \\
(0.003)\end{array}$ & & $\begin{array}{c}0.063 \\
(0.008)\end{array}$ & & $\begin{array}{c}0.045 \\
(0.008)\end{array}$ \\
\hline $\begin{array}{l}\text { CRA Elig } \\
\alpha^{(2)}\end{array}$ & IRLT80 & $\begin{array}{c}0.051 \\
(0.002)\end{array}$ & & $\begin{array}{c}0.114 \\
(0.005)\end{array}$ & & $\begin{array}{c}0.081 \\
(0.005)\end{array}$ \\
\hline $\begin{array}{l}\text { Interactic } \\
\alpha_{\lambda}^{(1)}\end{array}$ & $m: L O W$ & $O D \times R E$ & LEND & $\begin{array}{r}-0.062 \\
(0.008)\end{array}$ & & $\begin{array}{r}-0.036 \\
(0.008)\end{array}$ \\
\hline $\begin{array}{l}\text { Interactic } \\
\alpha_{\lambda}^{(2)}\end{array}$ & $m: I R L T 8$ & $\times R E L \_I$ & $N D$ & $\begin{array}{r}-0.078 \\
(0.005)\end{array}$ & & $\begin{array}{r}-0.022 \\
(0.006)\end{array}$ \\
\hline
\end{tabular}


Table 6 (continued from previous page)

\begin{tabular}{lllllll}
\hline & \multicolumn{4}{c}{ Estimated Coefficients By Regression Specification } \\
Variable & $A$ & $A^{\prime}$ & $B$ & $B^{\prime}$ & $C$ & $C^{\prime}$ \\
\hline
\end{tabular}

\section{Risk Variables}

Loan-to-value ratio $\nu$

$\begin{array}{lcccccc}75 \leq \nu<81 & -0.024 & -0.024 & -0.024 & -0.023 & -0.003 & -0.002 \\ & (0.002) & (0.002) & (0.002) & (0.002) & (0.005) & (0.005) \\ 81 \leq \nu<91 & 0.030 & 0.031 & 0.030 & 0.031 & 0.073 & 0.075 \\ & (0.003) & (0.003) & (0.003) & (0.003) & (0.006) & (0.006) \\ 91 \leq \nu<96 & 0.056 & 0.057 & 0.057 & 0.058 & 0.165 & 0.167 \\ & (0.003) & (0.003) & (0.003) & (0.003) & (0.006) & (0.006) \\ 96 \leq \nu<99 & 0.042 & 0.043 & 0.043 & 0.045 & 0.265 & 0.264 \\ & (0.004) & (0.004) & (0.004) & (0.004) & (0.011) & (0.011) \\ \nu \geq 99 & -0.049 & -0.048 & -0.046 & -0.043 & 1.24 & 1.24 \\ & (0.008) & (0.008) & (0.008) & (0.008) & (0.026) & (0.026)\end{array}$

Loan-to-income ratio $\ell$

$\begin{array}{lcccccc}\ell & -0.067 & -0.068 & -0.068 & -0.069 & -0.032 & -0.034 \\ \ell^{2} / 100 & (0.001) & (0.001) & (0.001) & (0.001) & (0.002) & (0.002) \\ & 0.46 & 0.47 & 0.47 & 0.47 & 0.21 & 0.22 \\ & (0.01) & (0.01) & (0.01) & (0.01) & (0.01) & (0.01)\end{array}$

$\begin{array}{lcccccc}\text { FANFRED } & -0.007 & -0.007 & -0.008 & -0.008 & -0.138 & -0.137 \\ & (0.003) & (0.003) & (0.003) & (0.003) & (0.008) & (0.008) \\ \text { SOLDOTH } & -0.095 & -0.096 & -0.092 & -0.092 & 0.034 & 0.034 \\ & (0.004) & (0.004) & (0.004) & (0.004) & (0.010) & (0.010)\end{array}$

CONFORMSIZE

$\begin{array}{lcccccc} & -0.180 & -0.180 & -0.179 & -0.179 & -0.000 & -0.001 \\ \text { PMI } & (0.004) & (0.004) & (0.004) & (0.004) & (0.009) & (0.009) \\ & 0.010 & 0.010 & 0.010 & 0.010 & 0.015 & 0.015 \\ \text { PCT_VAC } & (0.002) & (0.002) & (0.002) & (0.002) & (0.004) & (0.004) \\ & & & & & & \\ & 0.013 & 0.016 & 0.013 & 0.016 & 0.034 & 0.035 \\ & (0.005) & (0.005) & (0.005) & (0.005) & (0.011) & (0.011)\end{array}$

continued on next page 
Table 6 (continued from previous page)

\begin{tabular}{|c|c|c|c|c|c|c|}
\hline \multirow[b]{2}{*}{ Variable } & \multicolumn{6}{|c|}{ Estimated Coefficients By Regression Specification } \\
\hline & $A$ & $A^{\prime}$ & $B$ & $B^{\prime}$ & $C$ & $C^{\prime}$ \\
\hline \multicolumn{7}{|c|}{ Risk Variable Interaction Terms } \\
\hline \multicolumn{7}{|c|}{ Loan-to-value ratio $\nu$} \\
\hline $75 \leq \nu<81$ & & & & & $\begin{array}{r}-0.022 \\
(0.006)\end{array}$ & $\begin{array}{c}-0.023 \\
(0.006)\end{array}$ \\
\hline $81 \leq \nu<91$ & & & & & $\begin{array}{c}-0.052 \\
(0.007)\end{array}$ & $\begin{array}{r}-0.052 \\
(0.007)\end{array}$ \\
\hline $91 \leq \nu<96$ & & & & & $\begin{array}{r}-0.139 \\
(0.006)\end{array}$ & $\begin{array}{c}-0.139 \\
(0.006)\end{array}$ \\
\hline $96 \leq \nu<99$ & & & & & $\begin{array}{c}-0.261 \\
(0.012)\end{array}$ & $\begin{array}{c}-0.258 \\
(0.012)\end{array}$ \\
\hline$\nu \geq 99$ & & & & & $\begin{array}{r}-1.404 \\
(0.027)\end{array}$ & $\begin{array}{r}-1.402 \\
(0.027)\end{array}$ \\
\hline \multicolumn{7}{|c|}{ Loan-to-income ratio $\ell$} \\
\hline$\ell$ & & & & & $\begin{array}{c}-0.059 \\
(0.002)\end{array}$ & $\begin{array}{c}-0.059 \\
(0.002)\end{array}$ \\
\hline$\ell^{2} / 100$ & & & & & $\begin{array}{c}0.81 \\
(0.03)\end{array}$ & $\begin{array}{c}0.81 \\
(0.03)\end{array}$ \\
\hline FANFRED & & & & & $\begin{array}{c}0.143 \\
(0.009)\end{array}$ & $\begin{array}{c}0.142 \\
(0.009)\end{array}$ \\
\hline SOLDOTH & & & & & $\begin{array}{c}-0.167 \\
(0.011)\end{array}$ & $\begin{array}{c}-0.168 \\
(0.011)\end{array}$ \\
\hline CONFORMS & & & & & $\begin{array}{r}-0.194 \\
(0.010)\end{array}$ & $\begin{array}{c}-0.193 \\
(0.010)\end{array}$ \\
\hline PMI & & & & & $\begin{array}{c}0.002 \\
(0.005)\end{array}$ & $\begin{array}{r}-0.002 \\
(0.005)\end{array}$ \\
\hline$P C T_{-} V A C$ & & & & & $\begin{array}{r}-0.024 \\
(0.012)\end{array}$ & $\begin{array}{r}-0.021 \\
(0.012)\end{array}$ \\
\hline \multicolumn{7}{|c|}{ Other Control Variables } \\
\hline Intercept & $\begin{array}{c}2.45 \\
(0.01)\end{array}$ & $\begin{array}{c}2.45 \\
(0.01)\end{array}$ & $\begin{array}{c}2.44 \\
(0.01)\end{array}$ & $\begin{array}{c}2.44 \\
(0.01)\end{array}$ & $\begin{array}{c}2.24 \\
(0.01)\end{array}$ & $\begin{array}{c}2.24 \\
(0.01)\end{array}$ \\
\hline CLOANS & $\begin{array}{c}-0.073 \\
(0.007)\end{array}$ & $\begin{array}{c}-0.076 \\
(0.007)\end{array}$ & $\begin{array}{c}-0.074 \\
(0.007)\end{array}$ & $\begin{array}{c}-0.077 \\
(0.007)\end{array}$ & $\begin{array}{c}-0.071 \\
(0.007)\end{array}$ & $\begin{array}{r}-0.074 \\
(0.007)\end{array}$ \\
\hline LENDERS & $\begin{array}{c}0.170 \\
(0.024)\end{array}$ & $\begin{array}{c}0.181 \\
(0.024)\end{array}$ & $\begin{array}{c}0.171 \\
(0.024)\end{array}$ & $\begin{array}{c}0.182 \\
(0.024)\end{array}$ & $\begin{array}{c}0.157 \\
(0.024)\end{array}$ & $\begin{array}{c}0.168 \\
(0.024)\end{array}$ \\
\hline
\end{tabular}


Table 6 (continued from previous page)

\begin{tabular}{|c|c|c|c|c|c|c|}
\hline \multirow[b]{2}{*}{ Variable } & \multicolumn{6}{|c|}{ Estimated Coefficients By Regression Specification } \\
\hline & $A$ & $A^{\prime}$ & $B$ & $B^{\prime}$ & $C$ & $C^{\prime}$ \\
\hline \multicolumn{7}{|c|}{ Year Dummies } \\
\hline YR95 & $\begin{array}{r}-0.507 \\
(0.005)\end{array}$ & $\begin{array}{c}-0.508 \\
(0.005)\end{array}$ & $\begin{array}{r}-0.506 \\
(0.005)\end{array}$ & $\begin{array}{r}-0.507 \\
(0.005)\end{array}$ & $\begin{array}{c}-0.511 \\
(0.005)\end{array}$ & $\begin{array}{r}-0.512 \\
(0.005)\end{array}$ \\
\hline YR96 & $\begin{array}{c}-0.661 \\
(0.005)\end{array}$ & $\begin{array}{r}-0.662 \\
(0.005)\end{array}$ & $\begin{array}{c}-0.661 \\
(0.005)\end{array}$ & $\begin{array}{r}-0.662 \\
(0.005)\end{array}$ & $\begin{array}{c}-0.661 \\
(0.005)\end{array}$ & $\begin{array}{r}-0.663 \\
(0.005)\end{array}$ \\
\hline YR97 & $\begin{array}{r}-0.665 \\
(0.005)\end{array}$ & $\begin{array}{r}-0.666 \\
(0.005)\end{array}$ & $\begin{array}{r}-0.665 \\
(0.005)\end{array}$ & $\begin{array}{r}-0.665 \\
(0.005)\end{array}$ & $\begin{array}{r}-0.669 \\
(0.005)\end{array}$ & $\begin{array}{r}-0.670 \\
(0.005)\end{array}$ \\
\hline YR98 & $\begin{array}{c}-0.368 \\
(0.004)\end{array}$ & $\begin{array}{c}-0.368 \\
(0.004)\end{array}$ & $\begin{array}{c}-0.368 \\
(0.004)\end{array}$ & $\begin{array}{r}-0.368 \\
(0.004)\end{array}$ & $\begin{array}{c}-0.374 \\
(0.004)\end{array}$ & $\begin{array}{r}-0.375 \\
(0.004)\end{array}$ \\
\hline YR99 & $\begin{array}{c}-0.366 \\
(0.003)\end{array}$ & $\begin{array}{c}-0.366 \\
(0.003)\end{array}$ & $\begin{array}{c}-0.366 \\
(0.003)\end{array}$ & $\begin{array}{r}-0.366 \\
(0.003)\end{array}$ & $\begin{array}{c}-0.367 \\
(0.003)\end{array}$ & $\begin{array}{c}-0.367 \\
(0.003)\end{array}$ \\
\hline PUSTRUSS & $\begin{array}{c}0.238 \\
(0.002)\end{array}$ & $\begin{array}{c}0.238 \\
(0.002)\end{array}$ & $\begin{array}{c}0.238 \\
(0.002)\end{array}$ & $\begin{array}{c}0.238 \\
(0.002)\end{array}$ & $\begin{array}{c}0.238 \\
(0.002)\end{array}$ & $\begin{array}{c}0.238 \\
(0.002)\end{array}$ \\
\hline $\begin{array}{l}\text { F-Value } \\
\operatorname{Pr}>F\end{array}$ & $\begin{array}{r}102.08 \\
<0.001\end{array}$ & $\begin{array}{r}102.20 \\
<0.001\end{array}$ & $\begin{array}{r}101.57 \\
<0.001\end{array}$ & $\begin{array}{r}101.57 \\
<0.001\end{array}$ & $\begin{array}{r}95.78 \\
<0.001\end{array}$ & $\begin{array}{r}95.96 \\
<0.001\end{array}$ \\
\hline $\begin{array}{l}R^{2} \\
\text { Sample Size }\end{array}$ & 0.32 & 0.32 & 0.33 & $\begin{array}{c}0.33 \\
250,593\end{array}$ & 0.34 & 0.34 \\
\hline
\end{tabular}

NoTE. Table gives selected regression coefficients and standard errors (in parentheses) from OLS regressions of the spread on a mortgage against the specified variables; see discussion in text and equations $(A),(B)$ and $(C)$ for more details. All regressions contained a full set of MSA and lending institution dummies; the F-statistic from a test of the hypothesis that all dummies were jointly equal to zero is shown. 
Table 7: Effective Interaction of Lender and Borrower Types from Table 6

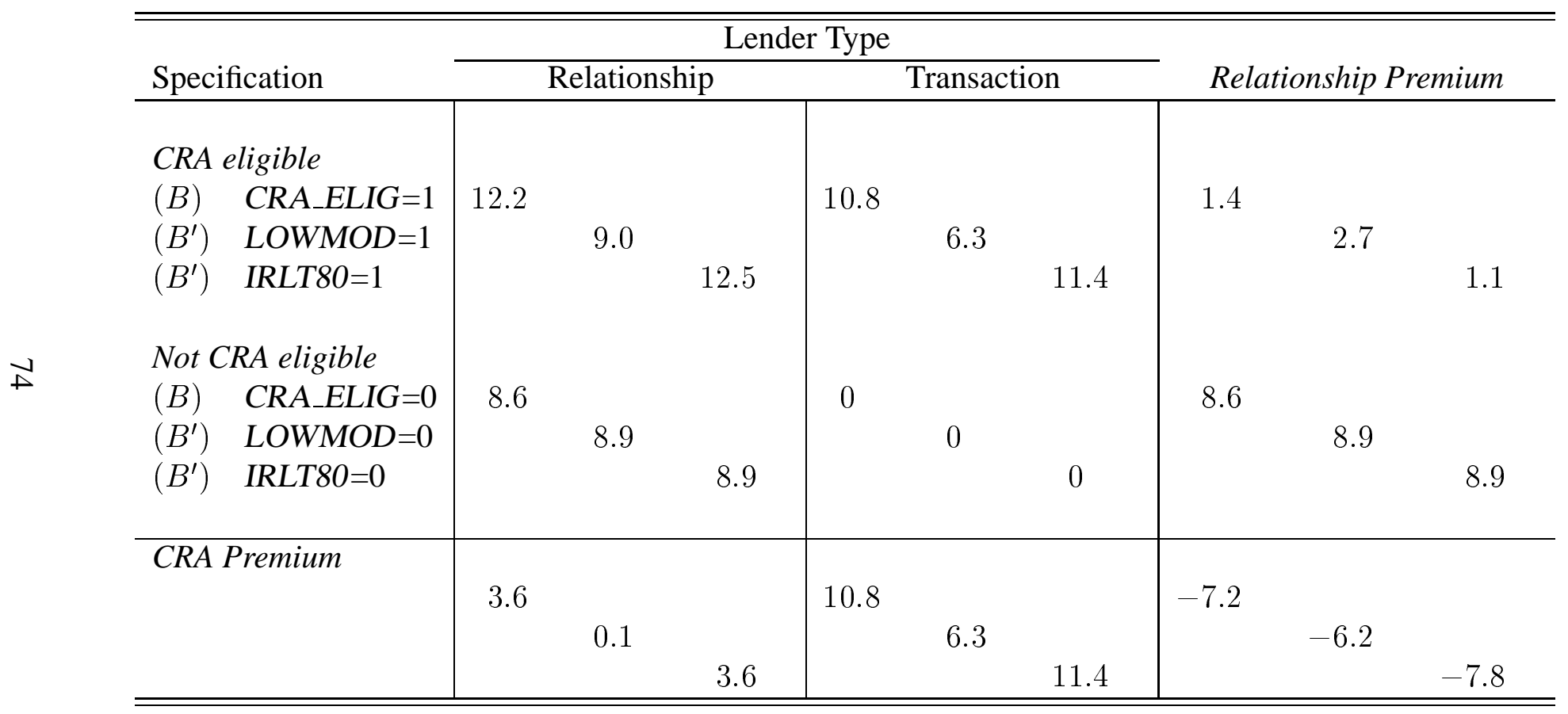

NotE. Table gives the difference in mortgage spreads (in basis points) of each combination of CRA-eligibility status and lender type relative to non-CRA-eligible borrowers at transaction lenders (the excluded category in the regressions). 
Table 8: Complete Regression Results For Higher Income Borrowers Only

\begin{tabular}{|c|c|c|c|}
\hline \multirow[b]{2}{*}{ Variable } & \multicolumn{3}{|c|}{ Regression Specification } \\
\hline & $A^{\prime}$ & $B^{\prime}$ & $C^{\prime}$ \\
\hline \multicolumn{4}{|c|}{ Relationship Lender: REL_LEND } \\
\hline$\lambda$ & $\begin{array}{c}.08906 \\
(.00498)\end{array}$ & $\begin{array}{c}.09024 \\
(.00500)\end{array}$ & $\begin{array}{c}.30039 \\
(.02278)\end{array}$ \\
\hline \multicolumn{4}{|c|}{ CRA Eligibility: LOWMOD } \\
\hline$\alpha^{(1)}$ & $\begin{array}{r}-.01098 \\
(.00601)\end{array}$ & $\begin{array}{c}.01634 \\
(.01254)\end{array}$ & $\begin{array}{c}.00547 \\
(.01255)\end{array}$ \\
\hline $\begin{array}{l}\text { Interacti } \\
\alpha_{\lambda}^{(1)}\end{array}$ & REL_LENI & $\begin{array}{r}-.03512 \\
(.01415)\end{array}$ & $\begin{array}{r}-.01161 \\
(.01420)\end{array}$ \\
\hline
\end{tabular}

Risk Variables

Loan-to-value ratio $\nu$

$\begin{array}{lccc}75 \leq \nu<81 & .00311 & .00309 & .02038 \\ 81 \leq \nu<91 & (.00328) & (.00328) & (.00677) \\ & .08146 & .08143 & .10721 \\ 91 \leq \nu<96 & (.00404) & (.00404) & (.00778) \\ & .12454 & .12447 & .20341 \\ 96 \leq \nu<98 & (.00390) & (.00390) & (.00742) \\ & .17869 & .17895 & .42593 \\ \nu \geq 99 & (.00817) & (.00817) & (.02066) \\ & .41322 & .41416 & 1.68317 \\ & (.01833) & (.01834) & (.03760)\end{array}$

Loan-to-income ratio $\ell$

\begin{tabular}{|c|c|c|c|}
\hline$\ell$ & $\begin{array}{r}-.3225 \\
(.0077) \\
\end{array}$ & $\begin{array}{r}-.3223 \\
(.0076) \\
\end{array}$ & $\begin{array}{r}-.2348 \\
(.0161) \\
\end{array}$ \\
\hline & & \multicolumn{2}{|c|}{ continued on next page } \\
\hline
\end{tabular}


Table 8 (continued from previous page)

\begin{tabular}{lccc}
\hline \multirow{2}{*}{ Variable } & \multicolumn{3}{c}{ Regression Specification } \\
$\ell^{2}$ & $A^{\prime}$ & $B^{\prime}$ & $C^{\prime}$ \\
\multirow{2}{*}{ FANFRED } & .0581 & .0581 & .0419 \\
& $(.0019)$ & $(.0019)$ & $(.0040)$ \\
SOLDOTH & -.0797 & -.0799 & -.1600 \\
CONFORMSIZE & $(.0039)$ & $(.0039)$ & $(.0105)$ \\
& .0623 & .0624 & .0479 \\
PMI & $(.0055)$ & $(.0055)$ & $(.0123)$ \\
& -.0804 & -.0803 & .0030 \\
PCT_VAC & $(.0047)$ & $(.0047)$ & $(.0108)$ \\
& .00895 & .00898 & .03058 \\
& $(.00289)$ & $(.00289)$ & $(.00593)$ \\
& .01505 & .01497 & .03391 \\
& $(.00701)$ & $(.00701)$ & $(.01455)$
\end{tabular}

Risk Variable Interaction Terms

Loan-to-value ratio $\nu$

$75 \leq \nu<81$

$-.02115$

$(.00771)$

$81 \leq \nu<91$

$-.03314$

$91 \leq \nu<96$

$(.00905)$

$-.10796$

$(.00865)$

$96 \leq \nu<99$

$-.29515$

$\nu \geq 99$

(.02244)

$-1.67394$

Loan-to-income ratio $\ell$

$(.04295)$

$\ell$

$-.11226$

$(.01809)$

$\ell^{2}$

.02071

$(.00450)$

continued on next page 
Table 8 (continued from previous page)

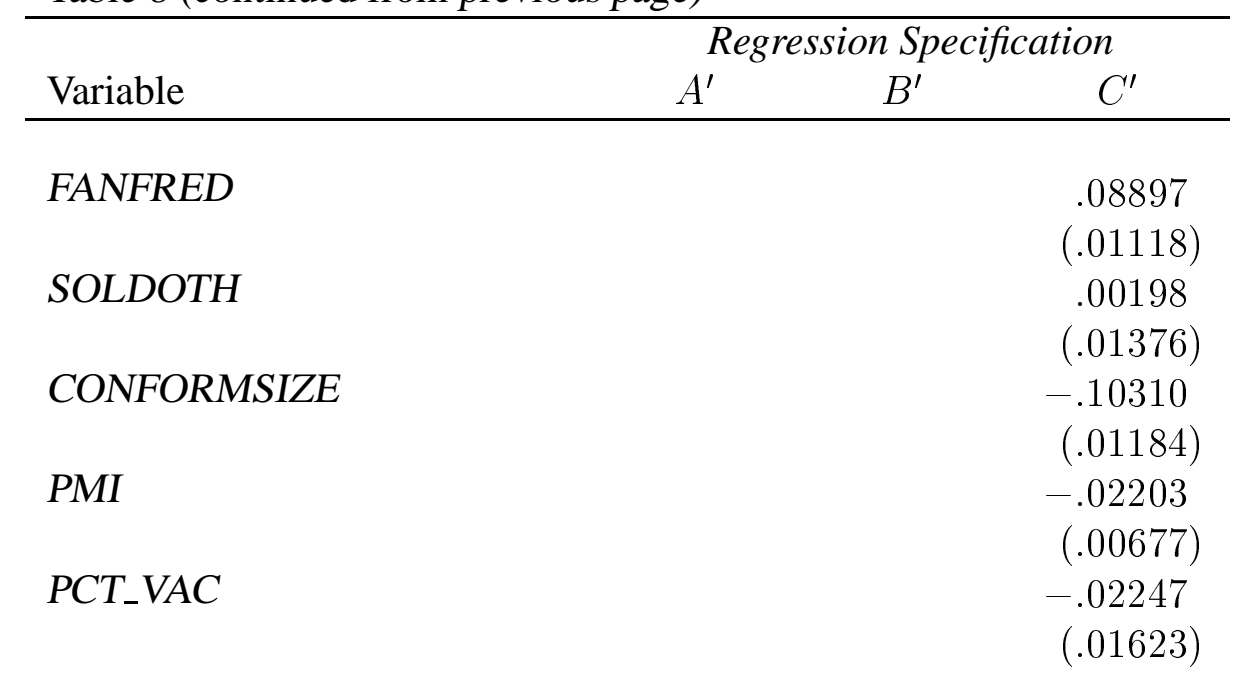

Other Control Variables

\begin{tabular}{lccc} 
Intercept & 2.56856 & 2.56747 & 2.41487 \\
CLOANS & $(.01189)$ & $(.01190)$ & $(.02149)$ \\
& -.03327 & -.03336 & -.03371 \\
LENDERS & $(.00845)$ & $(.00845)$ & $(.00838)$ \\
& .08423 & .08489 & .08196 \\
YR95 & $(.03060)$ & $(.03060)$ & $(.03032)$ \\
& -.45578 & -.45570 & -.45941 \\
YR96 & $(.00772)$ & $(.00772)$ & $(.00765)$ \\
YR97 & -.57568 & -.57555 & -.57878 \\
& $(.00642)$ & $(.00642)$ & $(-.00637)$ \\
YR98 & -.63019 & -.63014 & -.63401 \\
& $(.00683)$ & $(.00683)$ & $(.00678)$ \\
YR99 & -.35744 & -.35737 & -.36154 \\
& $(.00458)$ & $(.00458)$ & $(.00455)$ \\
POSTRUSSIA & -.36194 & -.36185 & -.36376 \\
& $(.00411)$ & $(.00411)$ & $(.00408)$ \\
& .22030 & .22029 & .22026 \\
& $(.00289)$ & $(.00289)$ & $(.00286)$ \\
\hline
\end{tabular}


Table 8 (continued from previous page)

\begin{tabular}{lccc}
\hline \multirow{2}{*}{ Variable } & \multicolumn{3}{c}{ Regression Specification } \\
& $A^{\prime}$ & $B^{\prime}$ & $C^{\prime}$ \\
F-Value & 44.52 & 44.53 & 44.18 \\
Pr $>$ F & $<0.0001$ & $<0.0001$ & $<0.0001$ \\
& & & \\
$R^{2}$ & 0.35 & 0.35 & 0.36 \\
Sample Size & & 119,435 & \\
\hline \hline
\end{tabular}

NOTE. Table gives selected regression coefficients and standard errors (in parentheses) from OLS regressions of the spread on a mortgage against the specified variables; see discussion in text and equation $\left(A^{\prime}\right)$ for more details. Here only higher-income borrowers (borrowers with incomes above $120 \%$ of the MSA median income) are included in the regression; CRA eligibility then stems purely from the borrower's neighborhood; if the borrower purchases a home in a lowerincome neighborhood (when LOWMOD = 1), the mortgage is eligible for CRA credit. All regressions contained a full set of MSA and lending institution dummies; the F-statistic from a test of the hypothesis that all dummies were jointly equal to zero is shown. 
Table 9: Effective Interaction of Lender and Borrower Types from Table 8

\begin{tabular}{l|cc|c}
\hline \hline \multirow{2}{*}{ Specification } & \multicolumn{2}{c}{ Lender Type } & \\
\cline { 2 - 3 } & & & \\
& & & \\
CRA eligiblionship & Transaction & Relationship Premium \\
$\left(B^{\prime}\right) \quad$ LOWMOD & 7.2 & 1.7 & 5.5 \\
Not CRA eligible & & & \\
$\left(B^{\prime}\right) \quad$ LOWMOD & 9.0 & 0 & 9.0 \\
& & & -3.5 \\
\hline CRA Premium & -1.8 & 1.7 & \\
\hline \hline
\end{tabular}

Note. Table gives the difference in mortgage spreads (in basis points) of each combination of CRA-eligibility status and lender type relative to non-CRAeligible borrowers at transaction lenders (the excluded category in the regressions). Here the dataset is limited to high-income borrowers, defined as borrowers with incomes greater than or equal to $120 \%$ of the MSA median income. 
Table 10: Restricted Sample Statistics Using Income Thresholds

\begin{tabular}{lcccc}
\hline \hline & \multicolumn{5}{c}{ Income Threshold (thousands) } \\
Variable & 60 & 80 & 100 & 120 \\
\hline & 1.87 & 1.88 & 1.90 & 1.91 \\
Mortgage Spread & $(0.49)$ & $(0.49)$ & $(0.49)$ & $(0.48)$ \\
& 173.80 & 200.19 & 225.08 & 248.62 \\
Loan Amount & $(73.45)$ & $(82.74)$ & $(93.88)$ & $(104.72)$ \\
& 81.38 & 79.90 & 78.49 & 77.43 \\
Loan-to-Value Ratio & $(13.71)$ & $(13.79)$ & $(13.86)$ & $(13.72)$ \\
& 1.87 & 1.72 & 1.60 & 1.50 \\
Loan-to-Income Ratio & $(0.64)$ & $(0.62)$ & $(0.63)$ & $(0.63)$ \\
& & & & \\
& & - Percent- & \\
Relationship Lender & 74.93 & 74.43 & 74.19 & 74.03 \\
LOWMOD & 4.00 & 3.38 & 2.98 & 2.78 \\
FANFRED & 70.89 & 64.44 & 56.34 & 48.81 \\
SOLDOTH & 12.43 & 17.78 & 24.24 & 30.13 \\
CONFORMSIZE & 86.62 & 77.00 & 65.64 & 55.06 \\
PMI & 30.96 & 23.72 & 17.36 & 12.87 \\
& \multicolumn{4}{c}{} \\
Observations & 114,280 & 60,363 & 32,190 & 17,810 \\
& & & \\
\hline \hline
\end{tabular}

NOTE. Table gives sample statistics for subsamples of our primary dataset; households were included only if their reported annual income exceeded the indicated threshold (in thousands of real 1996 dollars). 
Table 11: Results Using Absolute Income Thresholds

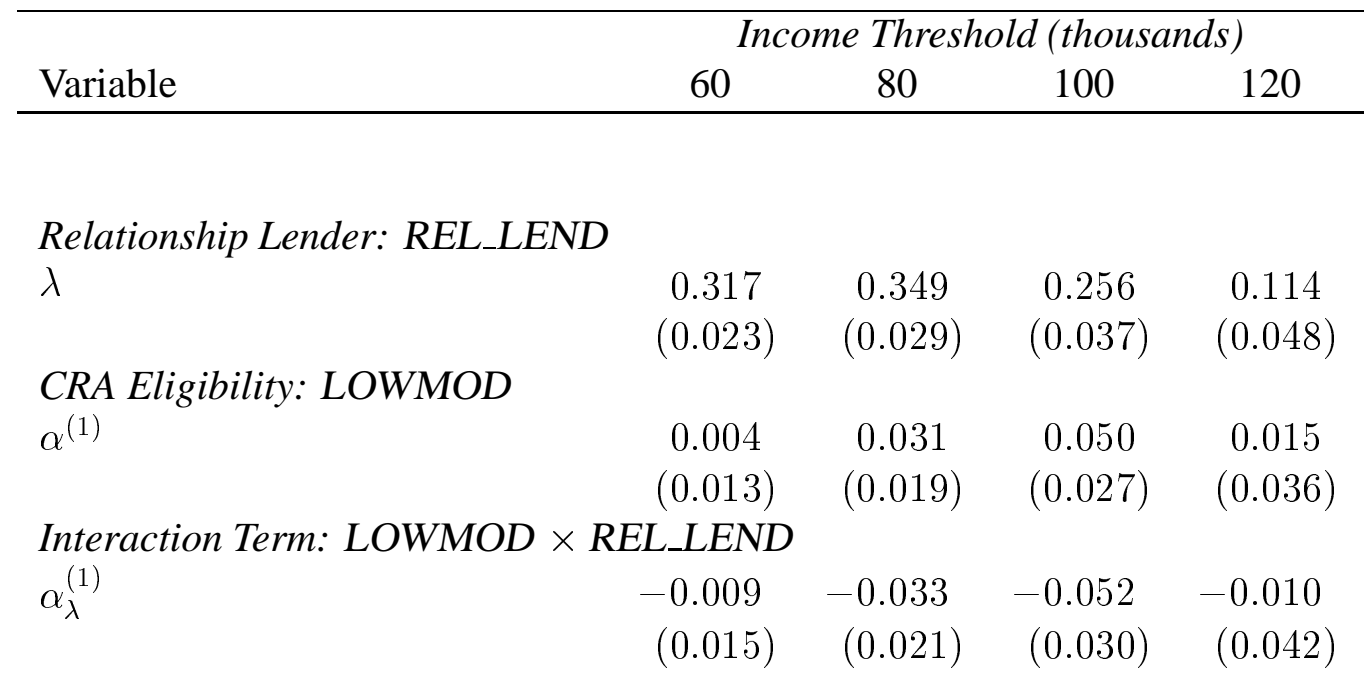

\section{Risk Variables}

Loan-to-value ratio $\nu$

$\begin{array}{lcccc}75 \leq \nu<81 & 0.024 & 0.019 & 0.005 & 0.024 \\ & (0.007) & (0.009) & (0.012) & (0.015) \\ 81 \leq \nu<91 & 0.115 & 0.112 & 0.112 & 0.113 \\ & (0.008) & (0.011) & (0.014) & (0.019) \\ 91 \leq \nu<96 & 0.214 & 0.232 & 0.241 & 0.271 \\ & (0.008) & (0.011) & (0.015) & (0.020) \\ 96 \leq \nu<98 & 0.394 & 0.449 & 0.400 & 0.658 \\ & (0.022) & (0.037) & (0.059) & (0.111) \\ \nu \geq 99 & 1.633 & 1.801 & 1.753 & 1.828 \\ & (0.039) & (0.050) & (0.075) & (0.111)\end{array}$

Loan-to-income ratio $\ell$

$\begin{array}{lllll}\ell & -0.238 & -0.201 & -0.240 & -0.286\end{array}$

$\begin{array}{llll}(0.016) & (0.020) & (0.026) & (0.036)\end{array}$

continued on next page 
Table 11 (continued from previous page)

\begin{tabular}{lcccc}
\hline \multirow{2}{*}{ Variable } & \multicolumn{5}{c}{ Income Threshold (thousands) } \\
\hline \multirow{2}{*}{$\ell^{2}$} & 60 & 80 & 100 & 120 \\
\multirow{2}{*}{ FANFRED } & 0.043 & 0.034 & 0.045 & 0.059 \\
& $(0.004)$ & $(0.005)$ & $(0.007)$ & $(0.010)$ \\
SOLDOTH & -0.160 & -0.173 & -0.163 & -0.152 \\
CONFORMSIZE & $(0.011)$ & $(0.014)$ & $(0.020)$ & $(0.027)$ \\
& 0.049 & 0.026 & 0.043 & 0.023 \\
PMI & $(0.012)$ & $(0.015)$ & $(0.018)$ & $(0.022)$ \\
& 0.004 & -0.017 & -0.030 & -0.067 \\
PCT_VAC & $(0.011)$ & $(0.013)$ & $(0.018)$ & $(0.024)$ \\
& 0.028 & 0.031 & 0.037 & 0.059 \\
& $(0.006)$ & $(0.009)$ & $(0.014)$ & $(0.020)$ \\
& 0.036 & 0.025 & 0.010 & -0.020 \\
& $(0.016)$ & $(0.020)$ & $(0.026)$ & $(0.033)$
\end{tabular}

Risk Variable Interaction Terms

Loan-to-value ratio $\nu$

$75 \leq \nu<81$

$81 \leq \nu<91$

$\begin{array}{llll}-0.025 & -0.018 & 0.008 & -0.011\end{array}$

$\begin{array}{llll}(0.008) & (0.010) \quad(0.013) \quad(0.017)\end{array}$

$\begin{array}{llll}-0.035 & -0.024 & -0.012 & -0.002\end{array}$

$91 \leq \nu<96$

$\begin{array}{llll}(0.009) & (0.012) & (0.017) & (0.023)\end{array}$

$\begin{array}{llll}-0.109 & -0.107 & -0.096 & -0.092\end{array}$

$96 \leq \nu<99$

$\begin{array}{llll}(0.009) & (0.012) \quad(0.018) & (0.025)\end{array}$

$\nu \geq 99$

$\begin{array}{llll}-0.272 & -0.334 & -0.275 & -0.512\end{array}$

$\begin{array}{llll}(0.024) \quad(0.041) & (0.065) \quad(0.120)\end{array}$

$\geq 99$

$\begin{array}{llll}-1.588 & -1.625 & -1.557 & -1.804\end{array}$

Loan-to-income ratio $\ell$

$\begin{array}{llll}(0.046) & (0.063) \quad(0.094) \quad(0.139)\end{array}$
$\ell$
$\ell^{2}$

$\begin{array}{llll}-0.119 & -0.204 & -0.125 & 0.012\end{array}$

$\begin{array}{llll}(0.018) & (0.023) \quad(0.030) & (0.041)\end{array}$

$\begin{array}{llll}0.022 & 0.051 & 0.036 & 0.005\end{array}$

$(0.005) \quad(0.006) \quad(0.008) \quad(0.011)$

continued on next page 
Table 11 (continued from previous page)

\begin{tabular}{lcccc}
\hline \multirow{2}{*}{ Variable } & \multicolumn{5}{c}{ Income Threshold (thousands) } \\
FANFRED & 60 & 80 & 100 & 120 \\
\multirow{2}{*}{ SOLDOTH } & 0.086 & 0.076 & 0.055 & 0.041 \\
& $(0.012)$ & $(0.015)$ & $(0.021)$ & $(0.028)$ \\
CONFORMSIZE & 0.005 & 0.011 & -0.027 & -0.002 \\
& $(0.014)$ & $(0.017)$ & $(0.020)$ & $(0.025)$ \\
PMI & -0.101 & -0.088 & -0.083 & -0.047 \\
& $(0.012)$ & $(0.015)$ & $(0.019)$ & $(0.026)$ \\
PCT_VAC & -0.021 & -0.033 & -0.040 & -0.067 \\
& $(0.007)$ & $(0.010)$ & $(0.016)$ & $(0.023)$ \\
& -0.016 & -0.010 & 0.017 & 0.051 \\
& $(0.017)$ & $(0.023)$ & $(0.029)$ & $(0.037)$
\end{tabular}

Other Control Variables

\begin{tabular}{lcccc} 
Intercept & 2.405 & 2.385 & 2.422 & 2.447 \\
CLOANS & $(0.022)$ & $(0.027)$ & $(0.035)$ & $(0.045)$ \\
& -0.033 & -0.022 & -0.024 & -0.020 \\
LENDERS & $(0.009)$ & $(0.012)$ & $(0.015)$ & $(0.020)$ \\
\multirow{2}{*}{ YR95 } & 0.088 & 0.076 & 0.094 & 0.070 \\
& $(0.031)$ & $(0.043)$ & $(0.054)$ & $(0.065)$ \\
YR96 & -0.454 & -0.464 & -0.481 & -0.502 \\
& $(0.008)$ & $(0.011)$ & $(0.015)$ & $(0.021)$ \\
YR97 & -0.577 & -0.580 & -0.581 & -0.592 \\
& $(0.007)$ & $(0.009)$ & $(0.013)$ & $(0.017)$ \\
YR98 & -0.633 & -0.643 & -0.664 & -0.684 \\
& $(0.007)$ & $(0.010)$ & $(0.013)$ & $(0.018)$ \\
YR99 & -0.358 & -0.349 & -0.346 & -0.340 \\
POSTRUSSIA & $(0.005)$ & $(0.006)$ & $(0.009)$ & $(0.011)$ \\
& -0.363 & -0.373 & -0.378 & -0.396 \\
& $(0.004)$ & $(0.006)$ & $(0.008)$ & $(0.010)$ \\
F-Value & 0.221 & 0.215 & 0.213 & 0.215 \\
\hline & $(0.003)$ & $(0.004)$ & $(0.005)$ & $(0.007)$ \\
\hline
\end{tabular}


Table 11 (continued from previous page)

\begin{tabular}{lcccc}
\hline \multirow{2}{*}{ Variable } & \multicolumn{5}{c}{ Income Threshold (thousands) } \\
& 60 & 80 & 100 & 120 \\
\hline $\operatorname{Pr}>\mathrm{F}$ & $<.001$ & $<.001$ & $<.001$ & $<.001$ \\
& & & & \\
$R^{2}$ & 0.36 & 0.38 & 0.38 & 0.40 \\
Sample Size & 114,280 & 60,360 & 32,190 & 17,810 \\
\hline \hline
\end{tabular}

NoTE. Table gives selected regression coefficients and standard errors (in parentheses) from OLS regressions of the spread on a mortgage against the specified variables; see discussion in text and equation $\left(C^{\prime}\right)$ for more details. Here only those borrowers with reported annual incomes (in real 1996 dollars) exceeding the indicated thresholds were included in the regression; CRA eligibility then stems purely from the borrower's neighborhood; if the borrower purchases a home in a lower-income neighborhood (when $L O W M O D=1$ ), the mortgage is eligible for CRA credit. All regressions contained a full set of MSA and lending institution dummies; the F-statistic from a test of the hypothesis that all dummies were jointly equal to zero is shown. 